OPEN ACCESS

Edited by: Hansen Wang, University of Toronto, Canada

Reviewed by: Karen K. Szumlinski, University of California, Santa Barbara, USA Zuzana Justinova, National Institute on Drug Abuse $(N I H)$, USA

*Correspondence: David M. Lovinger lovindav@mail.nih.gov

Received: 30 September 2016 Accepted: 31 October 2016 Published: 11 November 2016

Citation: Johnson KA and Lovinger DM (2016) Presynaptic G Protein-Coupled Receptors: Gatekeepers of Addiction? Front. Cell. Neurosci. 10:264. doi: 10.3389/fncel.2016.00264

\section{Presynaptic G Protein-Coupled Receptors: Gatekeepers of Addiction?}

\author{
Kari A. Johnson and David M. Lovinger * \\ Section on Synaptic Pharmacology, Laboratory for Integrative Neuroscience, National Institute on Alcohol Abuse and \\ Alcoholism, National Institutes of Health, Bethesda, MD, USA
}

Drug abuse and addiction cause widespread social and public health problems, and the neurobiology underlying drug actions and drug use and abuse is an area of intensive research. Drugs of abuse alter synaptic transmission, and these actions contribute to acute intoxication as well as the chronic effects of abused substances. Transmission at most mammalian synapses involves neurotransmitter activation of two receptor subtypes, ligand-gated ion channels that mediate fast synaptic responses and G protein-coupled receptors (GPCRs) that have slower neuromodulatory actions. The GPCRs represent a large proportion of neurotransmitter receptors involved in almost all facets of nervous system function. In addition, these receptors are targets for many pharmacotherapeutic agents. Drugs of abuse directly or indirectly affect neuromodulation mediated by GPCRs, with important consequences for intoxication, drug taking and responses to prolonged drug exposure, withdrawal and addiction. Among the GPCRs are several subtypes involved in presynaptic inhibition, most of which are coupled to the $\mathrm{G}_{\mathrm{i} / \mathrm{o}}$ class of $\mathrm{G}$ protein. There is increasing evidence that these presynaptic $\mathrm{G}_{\mathrm{i} / \mathrm{o}}$-coupled GPCRs have important roles in the actions of drugs of abuse, as well as behaviors related to these drugs. This topic will be reviewed, with particular emphasis on receptors for three neurotransmitters, Dopamine (DA; $D_{1}$ and $\mathrm{D}_{2}$-like receptors), Endocannabinoids (eCBs; $\mathrm{CB} 1$ receptors) and glutamate (group II metabotropic glutamate (mGlu) receptors). The focus is on recent evidence from laboratory animal models (and some evidence in humans) implicating these receptors in the acute and chronic effects of numerous abused drugs, as well as in the control of drug seeking and taking. The ability of drugs targeting these receptors to modify drug seeking behavior has raised the possibility of using compounds targeting these receptors for addiction pharmacotherapy. This topic is also discussed, with emphasis on development of mGlu 2 positive allosteric modulators (PAMs).

Keywords: addiction, self-administration, presynaptic, GPCR, dopamine receptor, CB1 receptor, metabotropic glutamate receptor, allosteric modulator

\section{INTRODUCTION}

Drug and alcohol use disorders are prominent neuropsychiatric conditions that create substantial economic, health and societal costs. Substance abuse definitions have evolved over time, but key features include relapse to drug use even after prolonged abstinence, escalation of drug intake, tolerance to the effects of drugs, craving, and continued use despite adverse consequences to 
health, financial status and relationships (American Psychiatric Association, 2013; Hasin et al., 2013; Koob and Volkow, 2016). Repeated drug exposure produces neuroadaptations that contribute to pathological drug-related behaviors. These include long-term alterations in gene expression, protein regulation, anatomy, and synaptic function that collectively influence neural circuits that govern reward, motivation, and action control to produce maladaptive behaviors. In particular, abused drugs produce adaptations in limbic, associative, and sensorimotor cortico-basal ganglia circuits that alter responses to drugs and contribute to inflexible drug taking and seeking behaviors (for review see Gremel and Lovinger, 2016; Scofield et al., 2016). Drug-associated changes in the activity of the dorsal and ventral striatum (nucleus accumbens, NAc) heavily contribute to various aspects of drug intake. In addition, inputs to the NAc from regions such as the amygdala and bed nucleus of the stria terminalis (BNST) provide information about environmental stimuli associated with drug intake that contributes to relapse to drug seeking following abstinence (Stamatakis et al., 2014). Plasticity of glutamatergic neurotransmission in these circuits has been implicated as a major neurobiological process underlying addictive behaviors (Kalivas, 2009; Scofield et al., 2016). Therefore, it is critical to understand the cellular processes that contribute to drug-induced plasticity. Moreover, a reversal of synaptic dysfunction in these circuits could correct pathological behaviors and represents a promising approach to designing new therapeutic strategies for drug use disorders. In this context, neurotransmitter receptors that are poised to influence synaptic transmission in key addiction-relevant circuits are likely to play critical roles in the effects of abused drugs and as novel therapeutic targets.

G protein-coupled receptors (GPCRs; also known as 7 transmembrane domain or 7TM receptors) are a large class of metabotropic receptors for neurotransmitters and hormones that couple to heterotrimeric $G$ proteins. $G$ proteins mediate a wide variety of cellular functions, including, but not limited to, altering the production of second messengers such as cyclic adenosine monophosphate (cAMP), mobilizing internal calcium stores, modulating ion channel function, altering neurotransmitter release, and influencing gene expression. Upon activation of a GPCR, the heterotrimeric G protein dissociates into $\alpha$ and $\beta \gamma$ subunits, which then modulate the function of a diverse array of effector proteins to simultaneously influence many cellular functions (Latek et al., 2012). GPCRs are often classified by the $G$ protein $\alpha$ subunits with which they prefer to interact. This review will primarily focus on $\mathrm{G}_{\mathrm{i} / \mathrm{o}}$-coupled GPCRs, which are well-known modulators of neurotransmitter release (Figure 1). These receptors inhibit adenylyl cyclase to reduce production of the second messenger molecule cAMP. In addition to $G \alpha$-mediated effects, the $G \beta \gamma$ subunits liberated by GPCR activation can influence neuronal physiology via direct interactions with voltage-gated calcium channels, G proteinactivated inward-rectifying potassium (GIRK) channels, and vesicular release machinery. In the context of the presynaptic axon terminal, each of these mechanisms can contribute to the inhibition of neurotransmitter release in response to GPCR

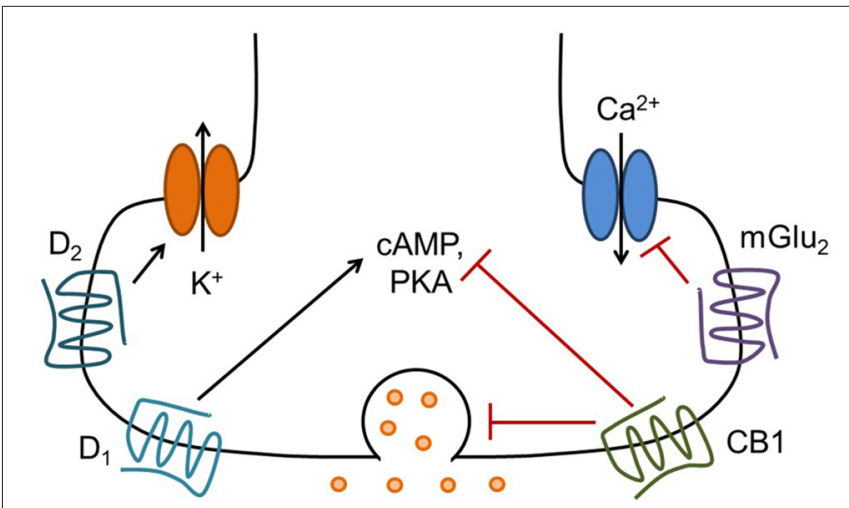

FIGURE 1 | Presynaptic G protein-coupled receptors (GPCRs) modulate neurotransmitter release via several mechanisms. Presynaptic $\mathrm{G}_{\mathrm{i} / \mathrm{o}}$-coupled GPCRs such as mGlu 2 , cannabinoid type 1 (CB1) and $\mathrm{D}_{2}$ can reduce the probability of neurotransmitter release by inhibiting calcium influx through voltage-gated calcium channels, by directly modulating the function of vesicle release machinery, and possibly by activating inwardly rectifying potassium channels to hyperpolarize or shunt the presynaptic terminal. These receptors also reduce cyclic adenosine monophosphate (CAMP) levels and protein kinase A (PKA) activity via inhibition of adenylyl cyclase, which may contribute to long-term regulation of neurotransmitter release. Conversely, presynaptic $D_{1}$ receptors, which are coupled to $G_{\mathrm{s}} / G_{\text {olf }}$ and activate PKA signaling, can increase neurotransmitter release. There are likely many other mechanisms involved in the regulation of neurotransmitter release by GPCRs, including activation of other signaling pathways and stimulation of protein synthesis (see Atwood et al., 2014b for further discussion).

activation (Kretz et al., 1986; Herlitze et al., 1996; Ikeda, 1996; Seino and Shibasaki, 2005).

Preclinical models of drug abuse including investigatoradministered passive drug exposure, conditioned place preference (CPP) and operant drug self-administration have been used to evaluate the multifaceted relationships between presynaptic GPCRs and drugs of abuse (for reviews of common animal models, see Belin-Rauscent et al., 2016; Scofield et al., 2016). Based on these studies, several prominent themes have emerged. First, GPCRs, particularly Dopamine (DA) receptors, are important mediators of the neurochemical and behavioral effects of drugs of abuse. Second, modulation of presynaptic GPCRs can alter neurochemical and behavioral responses to acute drug exposure in ways that would be predicted to either promote or constrain the rewarding and stimulating effects of a variety of abused drugs. Third, repeated exposure to drugs such as alcohol, cocaine, and nicotine produce long-lasting changes in the ability of some presynaptic GPCRs to modulate the release of neurotransmitters, particularly glutamate, in addictionrelevant circuits. Such drug-induced neuroadaptations are likely to play key roles in the transitions to problematic drug-related behaviors including escalation of drug taking and relapse following abstinence. Finally, pharmacological manipulation of presynaptic GPCRs can reduce seeking and taking of self-administered drugs in both rodent and non-human primate models, suggesting that targeting these receptors could be a viable therapeutic approach for treating addiction. The present review will highlight these themes using the examples 
of three well-known classes of GPCRs: DA receptors, which are important mediators of the CNS effects of abused drugs; cannabinoid type 1 (CB1) receptors; and group II metabotropic glutamate receptors (mGlus). We will then discuss recent progress towards translating preclinical findings into clinical therapeutics.

\section{DOPAMINE RECEPTORS}

DA is one of the few small molecule neurotransmitters that exclusively activate GPCRs in the mammalian brain, and thus only has modulatory neurophysiological and neurochemical effects. There are five different $\mathrm{DA}$ receptor subtypes $\left(\mathrm{D}_{1-5}\right)$ with the $\mathrm{D}_{1}$ and ${ }_{-5}$ subtypes generally coupled to $\mathrm{G}_{\mathrm{s} / \mathrm{olf}} \mathrm{G}$ proteins, and the $D_{2},-3$ and ${ }_{-4}$ coupled to $\mathrm{G}_{\mathrm{i} / \mathrm{o}}$ (for review see Beaulieu and Gainetdinov, 2011). DA receptors are found on both preand postsynaptic elements of many CNS neuronal subtypes. In some neurons, such as striatal medium spiny projection neurons (MSNs), it is likely that DA receptors mediate effects that are considered postsynaptic (e.g., changes in intracellular signaling, gene expression, and modulation of postsynaptic ionotropic glutamate receptor function) as well as effects that are presynaptic (i.e., modulating neurotransmitter release onto neighboring MSNs or neurons in striatal target regions such as the globus pallidus/ventral pallidum). The anatomical distribution of dopaminergic neurons is well circumscribed within the brain. The large majority of dopaminergic neuronal somata reside within the $\mathrm{A} 9$ and $\mathrm{A} 10$ ventral midbrain areas, also known as the substantia nigra pars compacta $(\mathrm{SNc})$ and ventral tegmental area (VTA), respectively. Efferent projections from these nuclei give rise to dense axonal fields in the dorsal striatum (from SNc) and ventral striatum/NAc (from VTA). Sparser DA projections innervate areas in the frontal cortex and allocortical areas such as the amygdala and hippocampus (Scatton et al., 1980; Gasbarri et al., 1997; Bjorklund and Dunnett, 2007; Lammel et al., 2008). These non-striatal projections mainly arise from the VTA (Gasbarri et al., 1997), although the SNc does give rise to a small hippocampal projection (Scatton et al., 1980). Midbrain dopaminergic neurons have crucial roles in movement initiation and control, signaling reward and salience of environmental events, and several other brain functions (Schultz, 2007; Wickens et al., 2007; Palmiter, 2008; Yin, 2016). A second, lesser known source of dopaminergic neurons is the ventral periaqueductal gray (PAG)/dorsal raphe nucleus (DRN) border region (Dougalis et al., 2012). This projection may have important roles in central processing of pain- and stress-related stimuli, but will not be discussed in detail in this review article.

Dopaminergic transmission is the direct target of a number of drugs of abuse, and is secondarily affected by virtually all abused drugs (reviewed in Volkow and Morales, 2015). The "stimulant" drugs such as cocaine, amphetamines and methylphenidate produce many of their CNS actions via molecular interactions with the dopamine transporter (DAT). This transporter is the main conduit for clearance of extracellular DA, strongly controlling effective concentrations of the neurotransmitter. Cocaine and methylphenidate inhibit transporter function, effectively blocking the reuptake of extracellular DA. The stimulant drugs thus prolong the time course and increase the extracellular spread of DA following vesicular release. Amphetamines can activate the reverse transport of intracellular DA to increase the extracellular content. This action also prevents uptake via the transporter, leading to large increases and spread of extracellular DA. The net effect of all these stimulant drug effects is to produce longer-lasting and more widespread activation of DA receptors, with subtle but important differences between the pure uptake blockers and amphetamines. The impact of these DAT-targeted drug effects are largest in the striatum, as the transporter is most highly expressed in the terminal fields in this structure. However, lesser effects can occur in cortical regions and even in the midbrain itself. Little is known about stimulant drug effects on PAG neurons and their axon terminals.

Other drugs of abuse increase dopaminergic synaptic transmission via distinct processes. One prominent mechanism is the disinhibition of midbrain dopaminergic neurons due to decreased activity or synaptic transmission from GABAergic neurons. This mechanism likely accounts for the DA enhancing effects of, benzodiazepines, cannabinoids, and opiates (Johnson and North, 1992; Szabo et al., 2002; Lupica and Riegel, 2005; Tan et al., 2010), and plays a part in the actions of nicotine (Pidoplichko et al., 2004). In the case of cannabinoids, $\mathrm{G}_{\mathrm{i} / \mathrm{o}}$-coupled GPCRs activated by these drugs are present on GABAergic presynaptic terminals that synapse onto midbrain dopaminergic neurons (Szabo et al., 2002; Lupica and Riegel, 2005). Activation of these GPCRs inhibits GABA release, effectively removing inhibition of DA neurons and allowing for greater firing and more DA release. Ethanol also appears to disinhibit dopaminergic neurons via effects on the firing of GABAergic neurons (Stobbs et al., 2004; Tateno and Robinson, 2011; but see Theile et al., 2011), although ethanol can also directly excite midbrain dopaminergic neurons via more direct effects on the neurons themselves (Melis et al., 2009; Morikawa and Morrisett, 2010).

As with the stimulant drugs, the main impact of other drugs of abuse on dopaminergic transmission occurs in target regions of the dopaminergic afferents (i.e., striatum and frontal cortex). All of these drugs increase extracellular DA in the dorsal and ventral striatum (Di Chiara and Imperato, 1988; Benwell and Balfour, 1997; Mathews et al., 2006). Early reports indicated that these effects were larger in the ventral striatum, and this region has been implicated in several aspects of drug use, abuse and relapse (Di Chiara and Imperato, 1988). However, drug effects in the dorsal striatum should not be ignored, as they likely contribute to the learning of goal-directed and habitual actions related to drug seeking and continued use (Gremel and Lovinger, 2016). Despite all that is known about the increases in extracellular DA produced by drugs of abuse, less is known about which receptors are responsible for translating this increase into intoxication and other acute drug actions. This subject clearly requires considerable additional research, but is outside the focus on presynaptic receptors in the present review article.

The roles of DA receptors in the effects of stimulant drugs have been examined in electrophysiological experiments. Application of amphetamine generally increases the firing of 
striatal neurons (e.g., Rebec et al., 1997; Glynn and Ahmad, 2003). Cocaine and amphetamine reliably inhibit afferent excitability and synaptic transmission in ventral striatum (Garcia-Munoz et al., 1991; Harvey and Lacey, 1996; Nicola et al., 1996; Glynn and Ahmad, 2003; Adrover et al., 2014; Dobbs et al., 2016), the globus pallidus and ventral pallidum (Floran et al., 1997; Dobbs et al., 2016), and the amygdala (Huang et al., 2003). In the ventral striatum, this effect appears to involve presynaptic suppression of neurotransmitter release and $\mathrm{D}_{1}$ receptor activation (Harvey and Lacey, 1996; Nicola et al., 1996). Although many physiological and behavioral effects of stimulant drugs cannot currently be attributed to specific preor postsynaptic receptor populations, a recent report by Dobbs et al. (2016) begins to shed light on this important question. This study found that cocaine increases firing of $\mathrm{D}_{1}$-expressing MSNs by reducing collateral inhibition via activation of $\mathrm{D}_{2}$ receptors on $\mathrm{D}_{2}$-expressing MSNs, and that presynaptic $M S N D_{2}$ receptors are critical mediators of acute locomotor responses to cocaine (Dobbs et al., 2016).

Changes in DA receptor expression and function have been examined following chronic exposure to both stimulant and non-stimulant drugs of abuse. For example, chronic cocaine exposure leads to $D_{1}$ supersensitivity in NAc (Nestler and Aghajanian, 1997), and increases in $\mathrm{D}_{2}$ receptor antagonist binding sites in the DS and NAc (Goeders and Kuhar, 1987). Increased sensitivity to behavioral effects of $\mathrm{D}_{2}$ agonists have also been observed (Ujike et al., 1990). However, reduced sensitivity of presynaptic autoreceptors, DA receptors on the dopaminergic neurons themselves, has also been observed following repeated cocaine administrations (Yi and Johnson, 1990). Imaging studies in both animals and humans reveal that decreased $D_{2}$ receptor availability is a striking common feature of chronic exposure to drugs of abuse including cocaine, alcohol, methamphetamine, heroin, nicotine, and cannabis (for review see Volkow et al., 2009). Importantly, reduced $D_{2}$ function following long-term drug abuse is thought to underlie reduced motivation for natural reinforcers.

The extent to which DA receptor ligands can mimic or alter behavioral actions of drugs of abuse has been widely studied (Table 1). Ligands for both $\mathrm{D}_{1}$ and $\mathrm{D}_{2}$ have cocaine-like effects when given acutely, and antagonists can block acute cocaine actions (Spealman et al., 1992; Baik, 2013). Activation of $\mathrm{D}_{2}$ receptors has been shown to blunt cocaine sensitization (Beyer and Steketee, 2002), while $\mathrm{D}_{2}$ antagonists or receptor

TABLE 1 | Behavioral effects of drugs targeting dopamine receptors.

\begin{tabular}{|c|c|c|}
\hline $\begin{array}{l}\text { Pharmacological } \\
\text { manipulation }\end{array}$ & Behavioral effect & Reference(s) \\
\hline$D_{1}$ agonist & cocaine-like effects & reviewed in Baik (2013) \\
\hline \multirow[t]{10}{*}{$\mathrm{D}_{1}$ antagonist } & $\begin{array}{l}\downarrow \text { cocaine locomotor activation } \\
\leftrightarrow \text { cocaine sensitization }\end{array}$ & $\begin{array}{l}\text { Cabib et al., 1991; Ushijima et al., } 1995 \\
\text { Kuribara and Uchihashi, 1993; Mattingly et al., 1994; Steketee, 1998; White et al., 1998; Karlsson et al., } \\
2008\end{array}$ \\
\hline & $\downarrow$ methamphetamine sensitization & Kuribara and Uchihashi, 1993 \\
\hline & $\uparrow$ cocaine SA & $\begin{array}{l}\text { Woolverton, 1986; Britton et al., 1991; Corrigall and Coen, 1991a; Hubner and Moreton, 1991; Caine and } \\
\text { Koob, } 1994\end{array}$ \\
\hline & $\downarrow$ amphetamine SA & Phillips et al., 1994; Pierre and Vezina, 1998 \\
\hline & $\downarrow$ MDMA SA & Brennan et al., 2009 \\
\hline & $\downarrow$ nicotine SA & Corrigall and Coen, 1991b; Kutlu et al., 2013; Hall et al., 2015 \\
\hline & $\downarrow$ cocaine seeking & Brown et al., 2012 \\
\hline & $\downarrow$ MDMA seeking & Schenk et al., 2011 \\
\hline & $\downarrow$ nicotine seeking & Liu et al., 2010 \\
\hline & $\downarrow$ heroin seeking & Shaham and Stewart, 1996 \\
\hline \multirow[t]{4}{*}{$D_{2}$ agonist } & cocaine-like effects & reviewed in Baik (2013) \\
\hline & $\downarrow$ cocaine sensitization & Beyer and Steketee, 2002 \\
\hline & $\downarrow$ cocaine CPP & Hummel and Unterwald, 2002 \\
\hline & $\uparrow$ cocaine seeking & $\begin{array}{l}\text { Self et al., 1996; De Vries et al., 1999; Spealman et al., 1999; Khroyan et al., 2000; De Vries et al., 2002; } \\
\text { Fuchs et al., } 2002\end{array}$ \\
\hline \multirow[t]{11}{*}{$\mathrm{D}_{2}$ antagonist } & $\leftrightarrow$ cocaine CPP & Spyraki et al., 1982; Cervo and Samanin, 1995; Nazarian et al., 2004 \\
\hline & $\leftrightarrow$ cocaine locomotor activation & Cabib et al., 1991; Ushijima et al., 1995 \\
\hline & $\leftrightarrow$ cocaine sensitization & Kuribara and Uchihashi, 1993; Mattingly et al., 1994; Shippenberg and Heidbreder, 1995; White et al., 1998 \\
\hline & $\downarrow$ methamphetamine sensitization & Kuribara and Uchihashi, 1993 \\
\hline & $\downarrow$ cocaine SA (mPFC) & Goeders and Smith, 1983 \\
\hline & $\uparrow$ cocaine SA & $\begin{array}{l}\text { Woolverton, 1986; Britton et al., 1991; Hubner and Moreton, 1991; Corrigall and Coen, 1991a; Caine and } \\
\text { Koob, } 1994\end{array}$ \\
\hline & $\downarrow$ amphetamine SA & Phillips et al., 1994 \\
\hline & $\uparrow$ MDMA SA & Brennan et al., 2009 \\
\hline & $\downarrow$ nicotine SA & Corrigall and Coen, 1991b \\
\hline & $\downarrow$ nicotine seeking & Liu et al., 2010 \\
\hline & $\downarrow$ heroin seeking & Shaham and Stewart, 1996 \\
\hline
\end{tabular}

$S A$, self-administration. 
knockout generally does not greatly alter acute locomotor activation, sensitization, or CPP (Spyraki et al., 1982; Cabib et al., 1991; Kuribara and Uchihashi, 1993; Mattingly et al., 1994; Cervo and Samanin, 1995; Shippenberg and Heidbreder, 1995; Ushijima et al., 1995; Vanderschuren and Kalivas, 2000; Nazarian et al., 2004; Welter et al., 2007; Sim et al., 2013). Deleting only those $\mathrm{D}_{2}$ receptors expressed on dopaminergic neurons themselves increases CPP for cocaine (Bello et al., 2011), highlighting the fact that antagonists or global knockout may not have any net effect due to different physiological roles of receptors expressed by different neuronal subtypes. Substantial literature indicates that $\mathrm{D}_{1}$ receptor activation has crucial roles in psychostimulant-induced behaviors, including locomotor activation, sensitization, CPP and self-administration (Kalivas, 1995; Baik, 2013). Generally, inhibiting or knocking out $\mathrm{D}_{1}$ receptors will attenuate locomotor activation, and CPP for cocaine (Cabib et al., 1991; Ushijima et al., 1995; Hummel and Unterwald, 2002). However, cocaine sensitization is not greatly altered by $\mathrm{D}_{1}$ antagonists or knockout (Kuribara and Uchihashi, 1993; Mattingly et al., 1994; Steketee, 1998; White et al., 1998; Vanderschuren and Kalivas, 2000; Karlsson et al., 2008), although it is reduced by inactivation of $D_{1}$-MSNs in NAc (Hikida et al., 2010; Chandra et al., 2013). Recent data from the Luscher laboratory provides compelling evidence that important aspects of the drug use disorder profile can be initiated by selective activation of the mesolimbic dopaminergic system, and that $\mathrm{D}_{1}$ receptors play a crucial role in these effects (Pascoli et al., 2015).

Studies evaluating the effects of manipulating DA receptor function on drug self-administration have revealed critical roles for these receptors in drug taking. Notably, blockade of $\mathrm{D}_{2}$ receptors in the medial prefrontal cortex has been shown to attenuate cocaine self-administration (Goeders and Smith, 1983). Systemic administration of D2 antagonists can enhance MDMA self-administration (Brennan et al., 2009). However, peripheral antagonist injections do not have consistent effects, due in part to biphasic effects at different doses (Woolverton, 1986; Britton et al., 1991; Corrigall and Coen, 1991a; Hubner and Moreton, 1991; Witkin et al., 1991; Caine and Koob, 1994). The literature on D1 antagonist effects on cocaine self-administration shows similar variability (Woolverton, 1986; Britton et al., 1991; Hubner and Moreton, 1991; Vanover et al., 1991; Caine and Koob, 1994). Other factors that may have influenced these outcomes were species and strain differences, differences in self-administration protocol, and differential impact of blocking $\mathrm{D}_{1}$ receptors on different neuronal targets at different drug doses. Knocking out all $\mathrm{D}_{1}$ receptors eliminates cocaine self-administration (Caine et al., 2007). Self-administration of MDMA is also prevented by a $D_{1}$ antagonist (Brennan et al., 2009). Intra-accumbens $D_{1}$ or $\mathrm{D}_{2}$ antagonist injection reduces amphetamine and nicotine self-administration (Corrigall and Coen, 1991b; Phillips et al., 1994), and $D_{1}$ antagonists also reduce drug-induced facilitation of amphetamine self-administration (Pierre and Vezina, 1998). In addition to the NAc shell subregion, the insular and parietal association cortices appear to be brain regions where $D_{1}$ receptors control self-administration (Kutlu et al., 2013; Hall et al., 2015).
DA receptors are also involved in the reinstatement of drug seeking following abstinence. For example, cue-induced reinstatement of nicotine seeking is reduced by both $D_{1}$ and $\mathrm{D}_{2}$ antagonists (Liu et al., 2010), and reinstatement of MDMA seeking is prevented by $\mathrm{D}_{1}$ antagonists (Schenk et al., 2011). Stress-induced reinstatement of heroin seeking is partially reduced by both $D_{1}$ and $D_{2}$ antagonists, with a larger effect of a non-selective DA receptor antagonist (Shaham and Stewart, 1996), whereas stress-induced reinstatement of cocaine seeking is only prevented by a $D_{1}$ antagonist (Brown et al., 2012). Conversely, activation of $\mathrm{D}_{2}$ enhanced reinstatement of both cocaine and heroin seeking (De Vries et al., 1999). It has been shown in several studies that $\mathrm{D}_{2}$ agonists can induce reinstatement of cocaine seeking behavior (Self et al., 1996; De Vries et al., 1999, 2002; Spealman et al., 1999; Khroyan et al., 2000; Fuchs et al., 2002). Mice lacking $D_{2}$ receptors show increased cocaine self-administration (Caine et al., 2002), but reinstatement of seeking induced by stress is attenuated in these mice (Sim et al., 2013). These seemingly conflicting results may be attributable to differences in the neurobiology of drug seeking for different drugs of abuse and different circuitry engaged by various stimuli that produce reinstatement of drug seeking.

\section{CB1 RECEPTORS}

Endocannabinoids (eCBs) are lipid metabolites that act as juxtacrine and paracrine modulators throughout the nervous system and body. Within the brain, eCBs produce their actions predominantly through activation of CB1, a class A GPCR that is almost exclusively localized to presynaptic terminals. The eCB name is obviously derived from the term cannabis, and this is due to the fact that $\mathrm{CB} 1$ is also the primary CNS molecular target for $\Delta^{9}$-tetrahydrocannabinol $\left(\Delta^{9} \mathrm{THC}\right)$, the major psychoactive ingredient in preparations of Cannabis sativa, which acts as a partial agonist at these receptors. The two major eCBs with synaptic actions are 2-arachidonoyl glycerol (2-AG) and arachidonoyl ethanolamide (AEA, also known as anandamide; for review see Lu and Mackie, 2016). The eCBs can be produced by virtually any cell in the brain, and the $\mathrm{CB} 1$ receptor shows widespread expression throughout the nervous system. The best known actions of CB1 involve presynaptic depression of neurotransmitter release, mediated via $\mathrm{G}_{\mathrm{i} / \mathrm{o}}$ activation. Downstream effectors involved in this inhibition include voltage-gated calcium channels, as-yet unidentified components of vesicle fusion machinery, and perhaps certain potassium channels (Chevaleyre et al., 2006).

A "retrograde" signaling mechanism in which eCBs are released from postsynaptic elements and act on presynaptic $\mathrm{CB} 1$ receptors, appears to be the predominant means for this neuromodulatory intercellular signaling. Both shortand long-term synaptic depression result from eCB signaling (Chevaleyre et al., 2006). The eCB-mediated short-term depression (STD) appears to persist only as long as eCBs occupy CB1 receptors (Heinbockel et al., 2005). The long-term depression (LTD) outlasts receptor occupancy and activation (Chevaleyre and Castillo, 2003). 
Since the discovery of CB1 and eCBs in the early 1990s, literature on the actions of drugs of abuse on this system has become vast. The most obvious interactions are with $\Delta^{9}$-THC derived from phytocannabinoids. As it is a partial agonist at CB1, $\Delta^{9}$-THC can mimic the synaptic depressant effects of eCBs (Hoffman and Lupica, 2013). Synthetic CB1 agonists have also been developed (e.g., WIN 55, 212-2, HU 210, CP55, 940 ), and these generally have high efficacy and produce strong synaptic depressant effects. Acute treatment with $\Delta^{9}$-THC or synthetic CB1 agonists produce well-characterized signs of intoxication and anti-nociception in humans and laboratory animals through CB1 activation (Wiley and Martin, 2003). Presynaptic CB1 receptors present on GABAergic terminals in the midbrain reduce inhibition of dopaminergic neurons (for additional discussion see Wang and Lupica, 2014; Covey et al., 2015). This mechanism is thought to account for the rewarding effects of $\Delta^{9}$-THC and other cannabinoid drugs, and is also likely to be a prominent mechanism through which eCBs contribute to brain mechanisms of reward.

Chronic exposure to $\Delta^{9}$-THC produces tolerance to many of the behavioral effects seen during initial drug exposure, but it has been harder to pin down signs of withdrawal and dependence, especially in laboratory animal models (Compton et al., 1990). Humans that regularly use cannabis preparations in large doses report craving, heightened anxiety, increased irritability, decreased food intake and sleep disruption following discontinuation of use (Haney et al., 1999; Budney et al., 2001;
Singleton et al., 2002; Gates et al., 2014). Other withdrawal signs are not apparent, but this is due mainly to the high lipophilicity of $\Delta^{9}$-THC which causes the drug to accumulate in fatty tissues, allowing for slow release and continuous low-level receptor activation. Following chronic $\Delta^{9}$-THC or synthetic $\mathrm{CB} 1$ agonist exposure, treatment with synthetic $\mathrm{CB} 1$ antagonists elicits signs of withdrawal including turning, chewing, digging, paw tremors and head shakes in laboratory animals (Cook et al., 1998; Rubino et al., 1998), supporting the idea these symptoms are largely suppressed by this continued post-withdrawal receptor activation. It has been hard to develop methods for self-administration of $\Delta^{9}$-THC and other CB1 agonists in laboratory animals, in part due to aversive effects of the compound. Intravenous self-administration has been reported, particularly in squirrel monkeys (Tanda et al., 2000; Justinova et al., 2003, 2005; Zangen et al., 2006), and CB1 antagonists reduce $\Delta^{9}$-THC self-administration as well as cue- and priminginduced reinstatement following extinction (Justinova et al., 2008). CPP for $\Delta^{9}$-THC and other CB1 agonists has also been demonstrated (Valjent and Maldonado, 2000; Braida et al., 2001). Notably, cannabinoid agonists can induce conditioned place aversion (CPA) in rodents, while CB1 antagonists can also induce CPP (Cheer et al., 2000). The net agonist-induced preference or aversion is critically dependent on dose. Thus, CB1 activation has mixed aversive and rewarding effects that could affect the abuse potential in different individuals. Administration of $\Delta^{9}$-THC also lowers the threshold for rewarding brain stimulation

TABLE 2 | Behavioral effects of drugs targeting cannabinoid type 1 (CB1) receptors.

\begin{tabular}{|c|c|c|}
\hline $\begin{array}{l}\text { Pharmacological } \\
\text { manipulation }\end{array}$ & Behavioral effect & Reference(s) \\
\hline $\begin{array}{l}\text { CB1 inverse } \\
\text { agonist }\end{array}$ & $\begin{array}{l}\downarrow \text { cocaine, morphine, nicotine, } \\
\text { morphine, methamphetamine CPP } \\
\leftrightarrow \text { alcohol CPP } \\
\leftrightarrow \text { cocaine SA } \\
\downarrow \text { MDMA SA } \\
\downarrow \text { nicotine SA } \\
\downarrow \text { heroin/morphine SA } \\
\downarrow \text { alcohol drinking } \\
\downarrow \text { alcohol SA } \\
\downarrow \text { THC SA } \\
\downarrow \text { cocaine seeking } \\
\downarrow \text { nicotine seeking } \\
\downarrow \text { heroin seeking } \\
\downarrow \text { alcohol seeking } \\
\downarrow \text { THC seeking }\end{array}$ & $\begin{array}{l}\text { Chaperon et al., 1998; Le Foll and Goldber } \\
\text { Yu et al., 2009; Fang et al., 2011; Rezayof } \\
\text { Pina and Cunningham, } 2014 \\
\text { Cossu et al., 2001; Lesscher et al., 2005; } \\
\text { Sala and Braida, 2005; Touriño et al., 2008 } \\
\text { Cohen et al., 2002; Shoaib, 2008; Simonne } \\
\text { Cossu et al., 2001; Navarro et al., 2001; S } \\
\text { reviewed in Pava and Woodward (2012) } \\
\text { Freedland et al., 2001; Navarro et al., } 2001 \\
\text { Tanda et al., 2000; Schindler et al., 2016 } \\
\text { De Vries et al., 2001; Xi et al., 2008; Orio e } \\
2014 \text {; McReynolds et al., 2016; Schindler } \\
\text { Cohen et al., 2005; Kodas et al., 2007; Sch } \\
\text { Fattore et al., 2005; Caillé and Parsons, } 20 \\
\text { de Bruin et al., 2011 } \\
\text { Justinova et al., 2008; Schindler et al., } 201\end{array}$ \\
\hline $\begin{array}{l}\text { CB1 neutral } \\
\text { antagonist }\end{array}$ & $\begin{array}{l}\leftrightarrow \text { cocaine SA } \\
\downarrow \text { nicotine SA } \\
\downarrow \text { THC SA } \\
\downarrow \text { cocaine seeking } \\
\downarrow \text { nicotine seeking } \\
\downarrow \text { THC seeking }\end{array}$ & $\begin{array}{l}\text { Schindler et al., } 2016 \\
\text { Gueye et al., 2016; Schindler et al., } 2016 \\
\text { Schindler et al., } 2016 \\
\text { Schindler et al., } 2016 \\
\text { Gueye et al., 2016; Schindler et al., } 2016 \\
\text { Schindler et al., } 2016\end{array}$ \\
\hline CB1 agonist & $\begin{array}{l}\uparrow \text { nicotine SA } \\
\uparrow \text { nicotine seeking }\end{array}$ & $\begin{array}{l}\text { Gamaleddin et al., } 2012 \\
\text { Gamaleddin et al., } 2012\end{array}$ \\
\hline $\begin{array}{l}\text { CB1 allosteric } \\
\text { modulator }\end{array}$ & $\begin{array}{l}\downarrow \text { cocaine seeking } \\
\downarrow \text { methamphetamine seeking }\end{array}$ & $\begin{array}{l}\text { Jing et al., } 2014 \\
\text { Jing et al., } 2014\end{array}$ \\
\hline
\end{tabular}


(reviewed in Gardner, 2002). Thus, there is some evidence for cannabis reward and withdrawal signs, and $\Delta^{9}$-THC clearly has abuse and dependence liability.

The eCB system is strongly implicated in the rewarding effects of a variety of abused drugs (Table 2; Justinova et al., 2009; Covey et al., 2015). Antagonists of CB1 impair acquisition or reinstatement of CPP for cocaine, morphine, and nicotine (Chaperon et al., 1998; Le Foll and Goldberg, 2004; Forget et al., 2005; Biala et al., 2009; Fang et al., 2011), but not ethanol (Pina and Cunningham, 2014). In contrast, CB1 knockout mice show reduced ethanol CPP (Houchi et al., 2005). Interestingly, CB1 knockout mice are not resistant to cocaine CPP, and in fact display a facilitation of CPP acquisition following stress (Miller et al., 2008). Consolidation, retrieval and reconsolidation of methamphetamine CPP are also disrupted by CB1 antagonists (Yu et al., 2009). The antagonist effects on morphine CPP are also observed with antagonist injection into the NAc (Azizi et al., 2009), and CB1 receptors in the central amygdala may also be involved (Rezayof et al., 2011). Nicotine CPP may also involve $\mathrm{CB} 1$ receptors in the basolateral amygdala (Hashemizadeh et al., 2014). ECBs and CB1 also contribute to the intake of several drugs of abuse in animal models. Both CB1 antagonist treatment and CB1 knockout decrease ethanol intake and preference in a standard two-bottle choice paradigm (reviewed in Pava and Woodward, 2012). Operant ethanol self-administration is also altered by antagonists (Freedland et al., 2001; Navarro et al., 2001; Caillé et al., 2007), and in CB1 knockout mice (Thanos et al., 2005). Considering other drugs of abuse, similar results have been obtained for self-administration of heroin (Navarro et al., 2001; Solinas et al., 2003), morphine (Cossu et al., 2001), MDMA (Sala and Braida, 2005; Touriño et al., 2008), and nicotine (Cohen et al., 2002; Shoaib, 2008). Modulation of drug-taking by CB1 receptors appears to be bidirectional, as CB1 agonist administration potentiates nicotine seeking and taking (Gamaleddin et al., 2012). Direct infusions of a CB1 antagonist into the VTA, but not the NAc, reduce nicotine self-administration (Simonnet et al., 2013), suggesting a pivotal role for VTA CB1 receptors. Different regions may be involved in reinstatement of nicotine seeking following extinction, as CB1 antagonists injected into the NAc shell, BLA, or mPFC impair reinstatement (Kodas et al., 2007). Similarly, cue-induced reinstatement of heroin seeking is inhibited by systemic injection of a CB1 antagonist or by direction infusion into the NAc core region or the PFC (Fattore et al., 2005; Caillé and Parsons, 2006; AlvarezJaimes et al., 2008). Systemic injections of CB1 antagonists also reduce drug-priming or cue-induced reinstatement of ethanol and nicotine seeking (Cohen et al., 2005; Forget et al., 2009; de Bruin et al., 2011). Collectively, these findings indicate that $\mathrm{CB} 1$ receptors in a variety of addiction-relevant brain regions contribute to various aspects of drug taking and seeking behavior, and that the receptors involved may vary between drugs of abuse.

The situation appears to be more complex for cocaine, as CB1 antagonists or knockout do not prevent self-administration of this drug (Cossu et al., 2001; Lesscher et al., 2005; Caillé et al., 2007; Xi et al., 2008). However, these antagonists reduce reinstatement of cocaine seeking produced by stress, drug-associated stimuli, or priming with the drug itself (De Vries et al., 2001; Ward et al., 2009; Vaughn et al., 2012; Jing et al., 2014; McReynolds et al., 2016), and also reduce cocaine seeking in a progressive ratio task and cocaine enhancement of intracranial self-stimulation (aka rewarding brain stimulation; $\mathrm{Xi}$ et al., 2008; Orio et al., 2009). "Impulsive" responding for cocaine in a delay-discounting task is also reduced by a CB1 antagonist (Hernandez et al., 2014). It is not fully clear if decreased intake is the result of one common eCB/CB1 action, or if several mechanisms are involved. Cocaine treatment mobilizes $\mathrm{eCB}$ production in the VTA, and thus suppresses GABAergic inhibition of DA neurons, resulting in enhanced DA release in the NAc (Wang et al., 2015). Inhibition of drug-induced increases in DA levels in the NAc is one consequence of CB1 antagonist treatment that could reduce the rewarding effects of drugs as well as drug intake (Cheer et al., 2007; Li et al., 2009; Wang et al., 2015). The DA-dampening effect of CB1 antagonists has been seen when CB1 antagonists are co-administered with several different drugs of abuse (Polissidis et al., 2014). However, other interactions with the $\mathrm{eCB} / \mathrm{CB} 1$ system could alter drug reward and intake. Indeed, one recent study demonstrated that deletion of CB1 from forebrain GABAergic neurons (including striatal MSNs) enhances DA release (Martín-García et al., 2016), indicating that $\mathrm{CB} 1$ receptors at multiple synapses regulate the neurochemical effects of cocaine, and perhaps other abused drugs (Miller et al., 2007).

The ability of CB1 antagonists such as rimonabant to reduce the rewarding properties of several drugs of abuse and inhibit reinstatement of drug seeking following abstinence led to the idea that $\mathrm{CB} 1$ receptor blockade could be a viable therapeutic approach for treating drug use disorders (reviewed in Justinova et al., 2009). However, clinical evaluation of rimonabant, which is an inverse agonist of CB1 receptors, revealed substantial adverse effects including production of psychiatric symptoms (e.g., depression, anxiety) as well as gastrointestinal symptoms (Kaur et al., 2016). Interestingly, recent efforts have focused on the development of $\mathrm{CB} 1$ receptor neutral antagonists rather than inverse agonists (e.g., AM4113; Kirilly et al., 2012). Importantly, recent preclinical studies demonstrate that, like rimonabant, neutral antagonists of $\mathrm{CB} 1$ reduce self-administration of $\Delta^{9}$-THC and nicotine, and can also prevent cue-induced reinstatement of $\Delta^{9}$-THC, nicotine, and cocaine seeking (Gueye et al., 2016; Schindler et al., 2016). These results suggest that development of neutral antagonists could represent a renewed opportunity to therapeutically target $\mathrm{CB} 1$ receptors.

In addition to neutral antagonists, efforts have been made to develop allosteric modulators of $\mathrm{CB} 1$ receptors as an alternative to inverse agonists. For example, ORG27569 binds to an allosteric site on CB1 receptors and enhances agonist binding but reduces agonist efficacy, thereby acting as a functional negative allosteric modulator (Price et al., 2005; Picone and Kendall, 2015). Importantly, ORG27569 reduces both drug-priming and cue-induced reinstatement of cocaine and methamphetamine seeking behavior (Jing et al., 2014), suggesting that allosteric modulation provides an additional alternative strategy for drug development. Intriguingly, the steroid hormone precursor 
pregnenolone was recently identified as a putative endogenous negative allosteric modulator of CB1 receptors (Vallée et al., 2014). Accordingly, pregnenolone reduces behavioral and physiological effects of $\Delta^{9}$-THC administration. Additional studies will be necessary to determine if negative allosteric modulators of CB1 have improved safety and tolerability profiles when compared with inverse agonists.

Chronic exposure to several different drugs of abuse results in different molecular and functional changes in the $\mathrm{eCB} / \mathrm{CB} 1$ system. Perhaps the easiest to understand are the effects of $\Delta^{9}$-THC and other CB1 agonists on CB1 expression and function. Injection of $\Delta^{9}$-THC in rodents once (Mato et al., 2004), or over several days (Mato et al., 2005; Nazzaro et al., 2012), results in loss of synaptic depression induced by eCBs and CB1 agonists. This loss of plasticity has been observed at glutamatergic synapses in dorsal and ventral striatum (Mato et al., 2005; Nazzaro et al., 2012; Hoffman and Lupica, 2013), as well as GABAergic synapses in hippocampus (Mato et al., 2004). Measurements of CB1 radioligand binding have provided mixed results, with some studies indicating that receptor numbers are diminished by this chronic drug exposure, while others report no change (Abood et al., 1993; Rodríguez De Fonseca et al., 1994; Romero et al., 1997; Mato et al., 2005). Measuring biochemical signals very proximal to CB1 activation using GTP $\gamma \mathrm{S}$ binding supports the idea that receptor coupling to $G$ proteins is compromised following chronic $\Delta^{9}$-THC treatment (Breivogel et al., 1999; Mato et al., 2005). This may signal internalization of receptors leading to alterations in $\mathrm{G}$ protein interaction. Until very recently it was difficult to measure $\mathrm{CB} 1$ internalization in presynaptic terminals, but a recent study using super resolution microscopy in hippocampal GABAergic terminals indicated that chronic $\Delta^{9}$-THC treatment does indeed produce internalization of CB1 (Dudok et al., 2015). Receptor localization returns to normal only several weeks after the end of drug exposure. It is also not clear if chronic $\Delta^{9}$-THC effects on $\mathrm{CB} 1$ are the consequence of direct ligand-receptor interactions, or occur secondarily to other molecular changes induced by the drug.

Use of cannabis-derived drugs have also been associated with decreased CB1 receptor availability in human ventral striatum, as determined with positron emission tomography using new CB1 ligands (Ceccarini et al., 2015). Other changes in human striatum have been noted in regular cannabis users, including decreased drug-induced DA release (Volkow et al., 2014). One report indicated that chronic cannabis drug use was associated with increased gray matter in young adult human NAc (Gilman et al., 2014), but a subsequent report indicated that most of this effect could be attributed to co-morbid alcohol use (Weiland et al., 2015). Thus, there is more work needed to elucidate cannabis drug effects on the human brain.

Among the non-cannabinoid drugs shown to alter $\mathrm{eCB} / \mathrm{CB} 1$ function are alcohol, cocaine, nicotine and opiates. Acute alcohol inhibition of the firing of NAc neurons appears to involve an interaction with $\mathrm{eCB} / \mathrm{CB} 1$ effects on afferents from the basolateral amydala (BLA; Perra et al., 2005). Interactions between acute alcohol exposure and $\mathrm{eCB} /$ cannabinoid actions have been observed in the BLA (Talani and Lovinger, 2015) and the central amgydala (CeA; Roberto et al., 2010). Chronic non-contingent alcohol exposure has been shown to eliminate eCB-dependent LTD at corticostriatal synapses in rodents (Xia et al., 2006; DePoy et al., 2013), and similar effects were observed following alcohol drinking (Adermark et al., 2011). Inhibition of GABAergic synapses by $\mathrm{CB} 1$ is also decreased following chronic ethanol exposure in both BLA and CeA (Varodayan et al., 2016a,b). A single in vivo exposure to cocaine also eliminates eCB-dependent LTD in the NAc (Fourgeaud et al., 2004), and effects of cocaine self-administration on glutamatergic synapses in the NAc shell involves an eCB-mediated mechanism (Ortinski et al., 2012). Following withdrawal after cocaine self-administration, the mGlu receptor/eCB-dependent LTD in the NAc is lost, and a different form of LTD develops that involves $\mathrm{mGlu}$ receptor-induced AMPA receptor trafficking (McCutcheon et al., 2011). Conversely, CB1 modulation of GABAergic transmission is sensitized following repeated cocaine exposure (Centonze et al., 2007). Reduced CB1 receptor expression has been observed in postmortem brain samples from human cocaine addicts (Álvaro-Bartolomé and García-Sevilla, 2013), and this was recapitulated in mice exposed to cocaine. Some studies report increased CB1 receptor expression levels despite reduced function, and this is likely due to the decreased $\mathrm{eCB}$ tone producing a compensatory upregulation of receptor levels (Blanco et al., 2014). A single in vivo exposure to the opiate drug oxycodone eliminates eCB-LTD in the dorsal striatum (Atwood et al., 2014a). It is clear that the effects of drugs of abuse on $\mathrm{CB} 1$ receptor function may be synapsespecific, drug-specific, and affect multiple aspects of the system including expression or function of enzymes that produce or degrade $\mathrm{eCBs}$ and the function of the $\mathrm{CB} 1$ receptor itself (Figure 2).

The effects of chronic exposure to cannabinoid drugs that produce addiction-related changes in behavior other than those discussed previously are not fully understood. An intriguing report of studies in mouse indicated that repeated injections of $\Delta^{9}$-THC leads animals to change their learned instrumental behavioral from goal-directed to habitual control (Nazzaro et al., 2012). This behavioral change is associated with the loss of striatal LTD discussed in the previous paragraph. Development of habits related to cannabis seeking and taking may well contribute to disorders associated with long-term heavy use of the drug. Determining the molecular and cellular mechanisms underlying habitual cannabis use will be an important subject of future research.

\section{GROUP II METABOTROPIC GLUTAMATE RECEPTORS}

Glutamate is the major fast excitatory neurotransmitter in the CNS. It exerts its neurophysiological effects through both ionotropic and neuromodulatory metabotropic receptors. The mGlu receptors (mGlus) are a group of class C GPCRs comprised of eight subtypes that are divided into three subgroups based on sequence homology, $\mathrm{G}$ protein-coupling specificity, and ligandbinding profiles (for review see Niswender and Conn, 2010). The group I mGlu receptors $\left(\mathrm{mGlu}_{1}\right.$ and $\mathrm{mGlu}_{5}$ ) couple to $\mathrm{G}_{q}$ family $\mathrm{G}$ proteins and are predominantly located postsynaptically, 




FIGURE 2 | Drug exposure disrupts presynaptic GPCR function. A variety of mechanisms may be involved in drug-induced reductions in presynaptic inhibition of neurotransmitter release. These include reduced receptor expression or surface levels and impaired coupling to $\mathrm{G}$ proteins or activation of intracellular signaling cascades. CB1 receptor signaling may also be reduced due to deficits in postsynaptic endocannabinoid (eCB) production. In addition, reduced cystine/glutamate exchange leads to decreased tonic activation of perisynaptic mGlu $2 / 3$ in the nucleus accumbens (NAc). Finally, chronic drug exposure could cause long-term depression (LTD) of neurotransmitter release that occludes further synaptic modulation by GPCRs.

whereas the group II $\left(\mathrm{mGlu}_{2}\right.$ and $\left.\mathrm{mGlu}_{3}\right)$ and group III $\left(\mathrm{mGlu}_{4}, \mathrm{mGlu}_{6}, \mathrm{mGlu}_{7}\right.$ and $\left.\mathrm{mGlu}_{8}\right)$ mGlu receptors couple to $\mathrm{G}_{\mathrm{i} / \mathrm{o}}$ family $\mathrm{G}$ proteins and frequently act as presynaptic autoand heteroreceptors. Although the group III mGlu receptors, particularly $\mathrm{mGlu}_{7}$, have received attention in the addiction field, the current review will focus on the preclinical evidence that group II mGlu receptors $\left(\mathrm{mGlu}_{2 / 3}\right)$ modulate the actions of drugs of abuse and represent potential therapeutic targets for the treatment of drug use disorders. Group II mGlu receptors are widely expressed in brain regions relevant to drug-related behaviors. Although physiological actions of postsynaptic group II $m$ Glu receptors have been identified (for example see Otani et al., 2002; Walker et al., 2015; Jin et al., 2016), they are best known for their ability to inhibit presynaptic neurotransmitter release at glutamatergic terminals. Group II mGlu receptor activation depresses glutamate release in critical regions such as the mPFC (Otani et al., 1999, 2002; Huang and Hsu, 2008; Walker et al., 2015), dorsal striatum (Lovinger and McCool, 1995; Kahn et al., 2001), NAc (Manzoni et al., 1997; Robbe et al., 2002a,b), central amygdala (Neugebauer et al., 2000), and BNST (Grueter and Winder, 2005). A variety of mechanisms might contribute to inhibition of neurotransmitter release by group II mGlu receptors, including inhibition of voltage-gated calcium channels (Anwyl, 1999; Robbe et al., 2002a; Kupferschmidt and Lovinger, 2015), interference with vesicle fusion and release machinery (Kupchik et al., 2008, 2011), and activation of presynaptic potassium channels (Anwyl, 1999).

Because group II mGlu receptors modulate glutamate release in key addiction-related brain circuits, it stands to reason that reduced expression and/or function of these receptors following drug exposure could contribute to dysregulated glutamate transmission. To test this hypothesis, a variety of anatomical and functional approaches have been used to assess the effects of drug exposure on $\mathrm{mGlu}_{2 / 3}$ expression and activity. Experiments evaluating drug- and withdrawalinduced changes in $\mathrm{mGlu}_{2}$ mRNA and protein levels have yielded somewhat conflicting results, and variables such as the drug of abuse, brain region, species, subject age and time point relative to drug exposure and withdrawal may contribute to such discrepancies. Multiple reports suggest that nicotine increases $\mathrm{mGlu}_{2}$ expression in the striatum during chronic exposure, but that receptor levels are normalized or decreased by abstinence (Counotte et al., 2011; Pistillo et al., 2016). No nicotine-induced changes in $\mathrm{mGlu}_{2}$ expression were observed in the PFC or midbrain (Pistillo et al., 2016). Cocaine exposure does not cause any change in $\mathrm{mGlu}_{2}$ or $\mathrm{mGlu}_{3}$ mRNA levels in cortical regions or the extended amygdala (Cannella et al., 2013), but increases $\mathrm{mGlu}_{2 / 3}$ density in the dorsal striatum of rhesus monkeys (Beveridge et al., 2011). In rats, alcohol dependance reduces $\mathrm{mGlu}_{2} \mathrm{mRNA}$ levels in the mPFC (Meinhardt et al., 2013). Evaluation of $\mathrm{mGlu}_{2}$ and $\mathrm{mGlu}_{3}$ mRNA levels in postmortem samples from human alcoholics has revealed decreased GRM2 levels in the anterior cingulate cortex (ACC; Meinhardt et al., 2013) and upregulation of GRM3 transcript in the hippocampus (Enoch et al., 2014). Conversely, human cocaine abusers show lower GRM3 transcript in the hippocampus (Enoch et al., 2014). In rats, methamphetamine self-administration followed by abstinence decreases $\mathrm{mGlu}_{2}$ protein levels in the PFC, dorsal striatum, and NAc (Schwendt et al., 2012). Intriguingly, extinction of methamphetamine self-administration reverses the 
downregulation of $\mathrm{mGlu}_{2}$ in striatal regions, whereas the effect persists in the case of abstinence. This finding suggests that active learning processes, and not the mere absence of drug exposure, can regulate plasticity of $\mathrm{mGlu}_{2}$ expression. Such observations of learning-induced plasticity in receptor expression provide potential neurobiological mechanisms for successful behaviorbased addiction interventions.

Studies employing GTP $\gamma \mathrm{S}$ binding, electrophysiological measures of synaptic transmission, and in vivo microdialysis to assess the impact of drugs of abuse on group II mGlu receptor function have yielded similarly varied results, and sometimes contrast with predictions based on changes in expression levels. For example, a history of nicotine exposure produces long-term decreases in $\mathrm{mGlu}_{2 / 3}$ function in the VTA, PFC, NAc, amydala, hippocampus and hypothalamus (Liechti et al., 2007; Counotte et al., 2011) despite a lack of evidence of widespread downregulation of $\mathrm{mGlu}_{2 / 3}$ expression (Pistillo et al., 2016). Repeated cocaine exposure (either investigator-administered or self-administered) impairs $\mathrm{mGlu}_{2 / 3}$-mediated depression of excitatory transmission in the PFC (Huang et al., 2007; Xie and Steketee, 2008; Kasanetz et al., 2013) and central amygdala (Neugebauer et al., 2000), whereas $\mathrm{mGlu}_{2 / 3}$-mediated LTD of excitatory transmission in the NAc remains intact following cocaine self-administration (Kasanetz et al., 2010). In conflict with these findings, Hao et al. (2010) reported that cocaine self-administration increases agonist-induced GTP $\gamma \mathrm{S}$ binding in the medial PFC and central amygdala as well as the VTA, BNST, and hippocampus. Interestingly, in this study increases in receptor efficacy were only observed using a long access model of cocaine self-administration, indicating that the experimental paradigm may also contribute to seeming discrepancies between studies. In alcohol-exposed rats, no change in agonist-induced GTP $\gamma \mathrm{S}$ binding was observed (Kufahl et al., 2011), whereas the ability of the same $\mathrm{mGlu}_{2 / 3}$ agonist to reduce extracellular glutamate levels in vivo was reduced (Meinhardt et al., 2013). Importantly, studies interrogating the effects of drug exposure on both expression and function suggest that increased expression does not necessarily correlate with functional readouts of receptor activity. For example, Xi et al. (2002) found that repeated cocaine exposure increases $\mathrm{mGlu}_{2}$ and $\mathrm{mGlu}_{3}$ protein levels in the PFC, but that agonist-stimulated GTP $\gamma S$ binding and efficacy for reducing extracellular glutamate levels were reduced. Such disparities between expression and function emphasize the importance of experimentally assessing receptor activity to clarify the functional effects of drug exposure.

Activation of group II mGlu receptors can modulate the neurochemical and behavioral effects of acute exposure to drugs of abuse, which commonly increase extracellular DA levels in both the dorsal striatum and NAc. Interestingly, cocaine exposure elicits higher levels of DA release in the NAc of mice lacking $\mathrm{mGlu}_{2}$ (Morishima et al., 2005). Conversely, group II mGlu receptor agonists attenuate DA release in the rat NAc following administration of amphetamine (Kim et al., 2005; Pehrson and Moghaddam, 2010). $\mathrm{mGlu}_{2 / 3}$ activation also reduces amphetamine-induced DA release in the rat dorsal striatum (Pehrson and Moghaddam, 2010) and cocaine-induced DA release in the caudate nucleus of squirrel monkeys (Bauzo et al., 2009). The mechanism for $\mathrm{mGlu}_{2 / 3}$ modulation of amphetamine-induced DA release is unclear, as a group II mGlu receptor agonist does not modulate DA release evoked by in vivo electrical stimulation of the VTA or by L-DOPA administration (Pehrson and Moghaddam, 2010). Interestingly, the effects of $\mathrm{mGlu}_{2 / 3}$ agonists on neurochemical responses to drug exposure are not limited to $\mathrm{DA}$; the $\mathrm{mGlu}_{2 / 3}$ agonist MGS0028 also reduces the increase in PFC serotonin levels following methamphetamine administration (Ago et al., 2011). Importantly, one study demonstrated that $\mathrm{mGlu}_{2 / 3}$-mediated attenuation of nicotine-induced DA release in the NAc shell only occurs in rats with a history of nicotine exposure, and only when the rats are in a context previously associated with nicotine exposure (D'Souza et al., 2011). This finding provides intriguing evidence that prior drug exposure induces plasticity in the ability of group II mGlu receptors to modulate the effects of drugs on DA transmission.

Group II mGlu receptor modulation of the neurochemical effects of exposure to psychostimulants correlates with decreased locomotor responses to amphetamine (Table 3, Cartmell and Schoepp, 2000; Pehrson and Moghaddam, 2010; Hanna et al., 2013; Arndt et al., 2014), methamphetamine (Ago et al., 2011; Hiyoshi et al., 2014), and phencyclidine (PCP; Hanna et al., 2013). Activation of both striatal and PFC $\mathrm{mGlu}_{2 / 3}$ may be involved in the observed suppression of psychomotor effects of stimulants, as intrastriatal $\mathrm{mGlu}_{2 / 3}$ agonist administration reduces locomotor responses to amphetamine (Mao and Wang, 1999) and intra-PFC injection of the $\mathrm{mGlu}_{2 / 3}$ agonist APDC attenuates locomotor activation by cocaine (Xie and Steketee, 2009). Administration of the $\mathrm{mGlu}_{2 / 3}$-selective agonist LY379268 also blocks the acquisition and expression of behavioral sensitization to amphetamine (Kim and Vezina, 2002; Kim et al., 2005). On the other hand, locomotor sensitization to cocaine is enhanced in $\mathrm{mGlu}_{2}$ knockout mice (Morishima et al., 2005). The synaptic mechanisms of $\mathrm{mGlu}_{2 / 3}$-modation of neurochemical and behavioral responses to drugs of abuse remain unclear, and may not be mediated by heteroreceptor activity on the terminals of dopaminergic neurons (Pehrson and Moghaddam, 2010). Future work could elucidate specific circuitlevel mechanisms by which presynaptic GPCRs such as $\mathrm{mGlu}_{2 / 3}$ modulate the pharmacodynamics of drugs of abuse.

Multiple lines of evidence support the idea that group II mGlu receptors regulate drug taking across a variety of paradigms and drugs of abuse. In rats, $\mathrm{mGlu}_{2 / 3}$ activation reduces motivation to self-administer cocaine as determined by a reduced breakpoint under a progressive ratio reinforcement schedule (Hao et al., 2010; Karkhanis et al., 2016). Studies evaluating self-administration of many drugs of abuse in rats have demonstrated that mGlu $_{2 / 3}$ activation by LY379268 reduces intake of amphetamine (Kim et al., 2005), methamphetamine (Crawford et al., 2013), alcohol (Sidhpura et al., 2010), and nicotine (Liechti et al., 2007). Conversely, the group II mGlu receptor-preferring antagonist LY341495 increases alcohol self-administration in rats (Zhou et al., 2013). In squirrel monkeys, LY379268 has been shown to reduce cocaine self-administration (Bauzo et al., 2009). However, a more recent report demonstrated a reduction in nicotine 
TABLE 3 | Behavioral effects of drugs targeting $\mathrm{mGlu}_{2 / 3}$.

\begin{tabular}{|c|c|c|}
\hline $\begin{array}{l}\text { Pharmacological } \\
\text { manipulation }\end{array}$ & Behavioral effect & Reference(s) \\
\hline mGlu $_{2 / 3}$ agonist & $\begin{array}{l}\downarrow \text { locomotor response to cocaine } \\
\downarrow \text { locomotor response to methamphetamine } \\
\downarrow \text { locomotor response to amphetamine } \\
\downarrow \text { amphetamine sensitization } \\
\downarrow \text { locomotor response to PCP } \\
\downarrow \text { cocaine SA } \\
\leftrightarrow \text { cocaine SA } \\
\downarrow \text { methamphetamine SA } \\
\downarrow \text { amphetamine SA } \\
\downarrow \text { nicotine SA } \\
\downarrow \text { alcohol SA } \\
\downarrow \text { cocaine seeking } \\
\downarrow \text { methamphetamine seeking } \\
\downarrow \text { nicotine seeking } \\
\downarrow \text { heroin seeking } \\
\downarrow \text { alcohol seeking }\end{array}$ & $\begin{array}{l}\text { Xie and Steketee, } 2009 \\
\text { Ago et al., 2011; Hiyoshi et al., } 2014 \\
\text { Mao and Wang, 1999; Cartmell and Schoepp, 2000; Pehrson and Moghaddam, 2010; Hanna } \\
\text { et al., 2013; Arndt et al., } 2014 \\
\text { Kim and Vezina, 2002; Kim et al., } 2005 \\
\text { Hanna et al., 2013 } \\
\text { Bauzo et al., 2009; Hao et al., 2010; Lu et al., 2012; Karkhanis et al., } 2016 \\
\text { Justinova et al., } 2016 \\
\text { Crawford et al., } 2013 \\
\text { Kim et al., 2005 } \\
\text { Liechti et al., 2007; Justinova et al., } 2016 \\
\text { Sidhpura et al., 2010 } \\
\text { Lu et al., 2007; Bauzo et al., 2009; Lu et al., 2012; Martin-Fardon and Weiss, 2012; Cannella } \\
\text { et al., 2013; Justinova et al., 2016 } \\
\text { Kufahl et al., 2013 } \\
\text { Liechti et al., 2007; Justinova et al., } 2016 \text {; Moro et al., } 2016 \\
\text { Bossert et al., 2004 } \\
\text { Zhao et al., 2006; Sidhpura et al., } 2010\end{array}$ \\
\hline $\mathrm{mGlu}_{2} \mathrm{PAM}$ & $\begin{array}{l}\downarrow \text { cocaine SA } \\
\downarrow \text { nicotine SA } \\
\downarrow \text { alcohol SA } \\
\downarrow \text { cocaine seeking } \\
\downarrow \text { methamphetamine seeking } \\
\downarrow \text { nicotine seeking } \\
\downarrow \text { alcohol seeking }\end{array}$ & $\begin{array}{l}\text { Jin et al., 2010; Dhanya et al., 2011, } 2014 \\
\text { Justinova et al., 2015; Li et al., } 2016 \\
\text { Augier et al., } 2016 \\
\text { Jin et al., } 2010 \\
\text { Caprioli et al., } 2015 \\
\text { Justinova et al., } 2015 \text {; Li et al., } 2016 \\
\text { Augier et al., } 2016\end{array}$ \\
\hline $\begin{array}{l}\mathrm{mGlu}_{2 / 3} \\
\text { antagonist }\end{array}$ & $\uparrow$ alcohol SA & Zhou et al., 2013 \\
\hline
\end{tabular}

self-administration by LY379268, but no effect on cocaine self-administration (Justinova et al., 2016). Although few studies have examined the circuitry by which $\mathrm{mGlu}_{2 / 3}$ activation reduces drug self-administration, experiments evaluating cocaine and nicotine self-administration have implicated both VTA and NAc receptor populations as potential mediators of reduced drug intake (Liechti et al., 2007; Lu et al., 2012).

Recent studies assessing the effects of genetic alteration of $\mathrm{mGlu}_{2}$ receptors provide further support for the notion that $\mathrm{mGlu}_{2}$ can regulate the reinforcing effects of repeated drug exposure. For example, genetic deletion of $\mathrm{mGlu}_{2}$ enhances both locomotor sensitization and CPP in response to repeated cocaine exposure (Morishima et al., 2005). In addition, mice lacking $\mathrm{mGlu}_{2}$ display increased alcohol consumption and preference in a two-bottle choice paradigm (Zhou et al., 2013). Interestingly, a naturally occurring mutation that introduces a stop codon in the gene for $\mathrm{mGlu}_{2}(\mathrm{Grm} 2 * 407)$ was recently identified in multiple lines of rats that are commonly employed in alcohol studies. Selectively bred alcohol-preferring $(\mathrm{P})$ rats, which consume large amounts of alcohol and display relapse-like behaviors, are homozygous for Grm2* 407. Intercrossing studies suggest that this allele is directly linked to increased alcohol consumption and preference in P rats (Zhou et al., 2013). Further investigation of lines of rats selectively bred for alcohol-related behaviors has also revealed an association between Grm2 $* 407$ and alcohol consumption (Wood et al., 2016). Importantly, this mutation is also present in many commercially available rat lines; therefore, extreme care must be taken when choosing strains and sources of rats for studying drug seeking and taking, particularly in regards to evaluating the effects of $\mathrm{mGlu}_{2}$ on drug-related behaviors. Conversely, rats lacking $\mathrm{mGlu}_{2}$ can serve as valuable controls for the specificity of $\mathrm{mGlu}_{2}$-targeted drug effects (Augier et al., 2016; Wood et al., 2016).

Following extinction of drug self-administration, pharmacological activation of group II mGlu receptors can reduce reinstatement of drug-seeking behavior. Experiments in rats evaluating the effects of $\mathrm{mGlu}_{2 / 3}$ activation on reinstatement of drug seeking by cues previously associated with drug self-administration show that $\mathrm{mGlu}_{2 / 3}$ activation attenuates reinstated seeking of cocaine ( $\mathrm{Lu}$ et al., 2007; Cannella et al., 2013), methamphetamine (Kufahl et al., 2013), alcohol (Zhao et al., 2006) and nicotine (Liechti et al., 2007; Moro et al., 2016). LY379268 also reduces context-induced reinstatement of heroin seeking (Bossert et al., 2004) and drug priming-induced reinstatement of methamphetamine seeking (Kufahl et al., 2013). Because stress is a significant factor contributing to relapse in human addictive disorders, $\mathrm{mGlu}_{2 / 3}$ activation has also been evaluated in models of stress-induced reinstatement of drug seeking. LY379268 blocks stress-induced reinstatement of cocaine (Martin-Fardon and Weiss, 2012) and alcohol seeking (Zhao et al., 2006; Sidhpura et al., 2010) in rats. Recent studies evaluating the effects of LY379268 on reinstatement of drug seeking in squirrel monkeys highlight the concept that activation of group II mGlu receptors may differentially reduce drug 
seeking depending on the specific drug of abuse and the type of reinstatement paradigm. Interestingly, LY379268 blocked both priming- and cue-induced reinstatement of nicotine seeking, but blocked cue-induced but not priming-induced reinstatement of cocaine seeking (Bauzo et al., 2009; Justinova et al., 2016). This finding may have intriguing implications for the therapeutic utility of group II mGlu receptor activation because efficacy in non-human primates could more closely predict human responses to drug treatments. On the whole, the most consistent finding is that $\mathrm{mGlu}_{2 / 3}$ activation could be useful for preventing relapse induced by environmental cues across a wide range of drugs of abuse.

Several studies have evaluated the potential contributions of $\mathrm{mGlu}_{2 / 3}$ receptors in various addiction-related circuits to inhibition of reinstated drug seeking. Numerous lines of evidence suggest that presynaptic $\mathrm{mGlu}_{2 / 3}$ receptors on excitatory terminals in the NAc play key roles. Producing an alcohol-dependent state in rats reduces $\mathrm{mGlu}_{2 / 3}$ expression and function in mPFC-NAc circuitry, and selectively restoring $\mathrm{mGlu}_{2}$ expression using a viral strategy reduces cue-induced reinstatement of alcohol seeking (Meinhardt et al., 2013). In addition, intra-NAc infusion of $\mathrm{mGlu}_{2 / 3}$ agonists reduces context-induced reinstatement of heroin seeking in rats (Bossert et al., 2004). Interestingly, the eugeroic drug modafinil, which has also been implicated as an anti-relapse drug (Soyka and Mutschler, 2016), reduces priming-induced reinstatement of cocaine seeking in rats by raising extracellular glutamate levels and indirectly activating group II mGlu receptors in the NAc core (Mahler et al., 2014). Further mechanistic insight into the role of NAc group II mGlu receptors in reinstatement of drug seeking comes from a series of studies evaluating the effects of repeated cocaine exposure on glutamate homeostasis. Cocaine decreases extrasynaptic glutamate levels in the NAc by decreasing the function of the glial cystine/glutamate exchange system (Baker et al., 2003). In turn, reduced tonic activation of presynaptic group II mGlu receptors disinhibits synaptic glutamate release, causing strengthened glutamatergic transmission at PFC-NAc synapses and disruption of several forms of synaptic plasticity (Moussawi et al., 2009). Treatment with $\mathrm{N}$-acetylcysteine (NAC), which boosts cystine/glutamate exchange, corrects cocaineinduced adaptations in NAc glutamatergic transmission and prevents cue- and priming-induced reinstatement of cocaine seeking in an $\mathrm{mGlu}_{2 / 3}$-dependent manner (Moussawi et al., 2009, 2011). These studies provide insight into the involvement of group II mGlu receptors in drug-induced neuroadaptations as well as a potential mechanism by which $\mathrm{mGlu}_{2 / 3}$ could be targeted for therapeutic purposes.

Additional evidence implicates group II mGlu receptors in both the VTA and the CeA as targets for blocking reinstatement of drug seeking. Infusion of LY379268 into the rat VTA reduces context-induced reinstatement of heroin seeking (Bossert et al., 2004) and priming-induced resintatement of cocaine seeking ( $\mathrm{Lu}$ et al., 2012). In addition, activation of group II mGlu receptors in the CeA prevents cue-induced reinstatement of cocaine seeking following prolonged extinction training (incubation of craving; Lu et al., 2007). It is possible that $\mathrm{mGlu}_{2 / 3}$ receptors (and particularly $\mathrm{mGlu}_{2}$ ) in various addiction-related circuits regulate drug seeking elicited by different stimuli. However, this hypothesis has not been exhaustively tested and may also vary between drugs of abuse.

It is worthwhile to consider that several studies have found that activation of group II mGlu receptors can also reduce instrumental responding for natural rewards (i.e., palatable foods) and/or inhibit reinstatement of extinguished food seeking in both rats and squirrel monkeys. However, this effect is typically less robust than reduction of drug self-administration and is observed with higher doses of agonist than the minimal effective dose required to reduce drug self-administration (Peters and Kalivas, 2006; Liechti et al., 2007; Jin et al., 2010; Kufahl et al., 2011, 2013; Lu et al., 2012; Justinova et al., 2016). Other studies have not observed a reduction in food self-administration following treatment with $\mathrm{mGlu}_{2 / 3}$ agonists (Baptista et al., 2004; Bossert et al., 2006; Zhao et al., 2006). A variety of factors could account for the observed impairment of food selfadministration, including a general reduction in motivation, a lessening of the rewarding properties of the food reinforcer, generation of an aversive state (e.g., nausea) by the $\mathrm{mGlu}_{2 / 3}$ agonist, or mild sedation. These potential non-specific effects of $\mathrm{mGlu}_{2 / 3}$ activation could limit the clinical utility of $\mathrm{mGlu}_{2 / 3}$ agonists or $\mathrm{mGlu}_{2}$ positive allosteric modulators (PAMs) for the treatment of drug abuse in humans; however, the common finding that lower doses of agonist are required to reduce drug self-administration vs. food self-administration suggests that a sufficient therapeutic window may exist to avoid adverse effects. Moreover, clinical studies of the $\mathrm{mGlu}_{2 / 3}$ agonist prodrug LY2142003 in schizophrenic patients suggest that activation of $\mathrm{mGlu}_{2 / 3}$ is generally safe and well-tolerated (Patil et al., 2007).

\section{CHALLENGES AND PROGRESS TOWARDS NOVEL PHARMACOTHERAPIES FOR ADDICTION: THE EXAMPLE OF mGlu $_{2}$}

Given the extensive evidence from preclinical models that activation of group II mGlu receptors can reduce seeking and taking of a variety of drugs of abuse, both academic groups and pharmaceutical companies have pursued drug discovery programs aimed at developing ligands that can be tested clinically to treat human drug use disorders. However, traditional approaches to developing drugs targeting these receptors have encountered a variety of challenges. For example, successful efforts to develop ligands targeting the orthosteric (glutamate) binding site of mGlu receptors have produced amino acid analogs, which often do not possess pharmacokinetic properties suitable for human dosing (Conn et al., 2014; however, see Mezler et al., 2010). Additionally, a common goal of drug discovery programs is to achieve high selectivity for a specific receptor subtype. This serves multiple purposes, including the creation of preclinical tools to validate specific targets for a given disorder. Moreover, subtype-selective drugs should be less prone to adverse effects mediated by off-target activity. Because the glutamate binding site is highly conserved between mGlu receptor subtypes, the development of highly selective ligands 
targeting this site has proven difficult. In recent years, discovery efforts have shifted to focus on allosteric modulators, which bind to a site on the receptor distinct from the orthosteric binding site and either enhance or inhibit the activity of the endogenous agonist.

PAMs potentiate the effects of endogenous agonists via multiple mechanisms that include enhancing the affinity of the receptor for the endogenous ligand and increasing efficiency of receptor coupling to downstream effectors (i.e., G proteins). Thus, PAMs of mGlu receptors can increase the potency of glutamate, as well as increase the maximal efficacy of receptor activation in the context of low receptor expression levels. Because allosteric binding sites are less conserved among GPCR families, many drug discovery campaigns have successfully created subtype-selective ligands (Conn et al., 2014). From a preclinical perspective, this success has permitted evaluation of specific mGlu receptor subtypes for treating drug use disorders. The development of several PAMs that are highly selective for $\mathrm{mGlu}_{2}$ and have properties suitable for in vivo testing has enabled the identification of $\mathrm{mGlu}_{2}$ as the major group II mGlu receptor subtype that could be pursued as a therapeutic strategy for reducing drug taking and seeking across a variety of classes of drugs. For example, the mGlu 2 PAM BINA, as well as other novel $\mathrm{mGlu}_{2}$-selective PAMs, reduce cocaine self-administration in rats (Jin et al., 2010; Dhanya et al., 2011, 2014). Similarly, the recently developed $\mathrm{mGlu}_{2}$ selective PAM AZD8529 modestly reduces self-administration of alcohol in rats (Augier et al., 2016) and reduces nicotine self-administration in both rats and squirrel monkeys (Justinova et al., 2015; Li et al., 2016). $\mathrm{mGlu}_{2}$ has also been implicated as a therapeutic target for relapse, as $\mathrm{mGlu}_{2}$ PAMs block cue-induced reinstatement of cocaine (Jin et al., 2010), methamphetamine (Caprioli et al., 2015), nicotine (Li et al., 2016), and alcohol (Augier et al., 2016) seeking in rats as well as cue- and priming-induced reinstatement of nicotine seeking in squirrel monkeys (Justinova et al., 2015). Interestingly, AZD8529 failed to block stress-induced reinstatement of alcohol seeking, suggesting that the effect of $\mathrm{mGlu}_{2}$ PAMs on reinstatement of drug seeking may be specific to particular stimuli (Augier et al., 2016).

A common challenge associated with the use of traditional agonists to treat CNS disorders is that agonists persistently activate the receptor, which can lead to desensitization, internalization, and thus tolerance to the drug effect. In support of this concept, a study by Liechti et al. (2007) evaluating the effects of the $\mathrm{mGlu}_{2 / 3}$ agonist LY379268 on nicotine self-administration found an initial robust decrease in self-administration; however, over the course of 14 days of treatment, rats gradually returned to their previous levels of responding for nicotine, indicating tolerance to the effects of LY379268. Because PAMs enhance responses to glutamate derived from synaptic or other endogenous sources, and typically do not directly activate the receptor in the absence of the endogenous agonist, they are more likely to maintain normal spatial and temporal receptor activation patterns, and thus are less likely to promote tolerance. Recent studies evaluating repeated dosing of the mGlu ${ }_{2}$ PAM AZD8529 demonstrated that this PAM persistently suppressed nicotine self-administration in rats (Li et al., 2016) and squirrel monkeys (Justinova et al., 2015), providing substantial support for the hypothesis that PAMs may possess an advantage over agonists with regards to tolerance. In contrast, $\mathrm{Li}$ et al. (2016) found that the ability of another $\mathrm{mGlu}_{2}$-selective PAM, AZD8418, to reduce nicotine self-administration in rats was susceptible to tolerance. These findings highlight the fact that not all PAMs of a given receptor behave similarly in vivo, which must be taken into account when designing studies evaluating their therapeutic potential. Interestingly, divergent results such as those noted here could provide insight into the pharmacological properties that are necessary for maintained suppression of drug intake, and thus provide an opportunity to optimize drugs for clinical use with these profiles in mind.

One potential drawback of therapeutic approaches that rely on pharmacological enhancement of presynaptic receptor function stems from multiple lines of evidence that the function of presynaptic GPCRs is impaired following chronic drug exposure. Particularly in cases in which the apparent loss of auto- or heteroreceptor activity could be caused by downregulation of receptor expression, it is possible that pharmacological activation of the remaining receptor population would be insufficient to restore modulation of neurotransmitter release. This concept was postulated by Meinhardt et al. (2013), who reported decreased $\mathrm{mGlu}_{2}$ mRNA levels in the prefrontal cortex of alcohol-dependent rats (Meinhardt et al., 2013). In this study, lentiviral rescue of $\mathrm{mGlu}_{2}$ expression in infralimbic PFC-NAc circuitry prevented cue-induced reinstatement of alcohol-seeking; however, the ability of pharmacological agents to mimic this rescue was not reported. As discussed above, numerous studies have reported efficacy of both agonists and PAMs of $\mathrm{mGlu}_{2}$ to decrease taking and seeking of various drugs of abuse, lending support to the idea that despite adaptations in $\mathrm{mGlu}_{2}$ function caused by chronic drug exposure, pharmacological interventions remain a viable strategy for correcting drug-related behaviors.

Recent progress towards the development of clinically useful drugs targeting $\mathrm{mGlu}_{2}$ creates an exciting opportunity to test the hypothesis that enhancing $\mathrm{mGlu}_{2}$ function will decrease drug seeking and taking in humans. Two mGlu 2 PAMs, AZD8529 (AstraZeneca) and JNJ-40411813 (Janssen Pharmaceuticals, Inc., in collaboration with Addex Therapeutics), have been evaluated in small clinical trials (Cross, 2013; Salih et al., 2015). To date, no major safety or tolerability concerns have been reported. A small trial assessed the ability of JNJ-40411813 to reduce cigarette craving and smoking in male smokers, and found a trend towards reduced craving but not a reduction of the number of cigarettes smoked (Salih et al., 2015). The U.S. National Institute on Drug Abuse is currently sponsoring a multi-site clinical trial to evaluate AZD8529 for smoking cessation in females (Clinicaltrails.gov identifier: NCT02401022). The results of this study will provide insight into the potential for translating preclinical evidence for the beneficial effects of $\mathrm{mGlu}_{2}$ PAMs into efficacy in human populations. Interestingly, clinical studies using NAC have shown a modest ability to promote abstinence 
from cocaine, cannabis, and nicotine (reviewed in McClure et al., 2014), providing additional, albeit indirect, support for the idea that increasing $\mathrm{mGlu}_{2}$ activity could reduce drug seeking in humans. Additional clinical trials examining the ability of drugs targeting $\mathrm{mGlu}_{2}$ to prevent relapse and reduce the use of a variety of drugs will be necessary to more thoroughly interrogate the specific human addictive behaviors that are most likely to be impacted by $m \mathrm{mGlu}_{2}$ activation.

\section{CONCLUDING REMARKS}

Substantial research using preclinical models of drug abuse has demonstrated key roles for presynaptic $G_{i / o}$-coupled GPCRs as mediators of the effects of abused drugs, substrates for neuroadaptations that impact behavior, and promising therapeutic targets for reducing drug intake and preventing relapse. These receptors include the three examples discussed above; however, this list is by no means exhaustive. For example, mu opioid receptors are important mediators of the rewarding effects of opiates such as heroin, and also undergo adaptations in function in response to drug exposure (Atwood et al., 2014a). Naltrexone, one of the few currently approved drugs for treating opioid and alcohol dependance, targets these opioid receptors. In addition, other mGlu receptors such as $\mathrm{mGlu}_{7}$ have been the subject of substantial preclinical investigation and may provide alternative targets for future drug discovery efforts ( $\mathrm{Li}$ et al., 2013; Mao et al., 2013). In addition, many mechanistic questions remain regarding the discrete synapses and circuits that are impacted by presynaptic GPCRs to modify drug intake and seeking. As the use of contemporary neuroscience techniques such as optogenetics and circuit-specific genetic manipulations become more widespread, enhanced understanding of how specific circuits control behaviors will provide opportunities to target GPCRs that modulate critical addiction circuitry to correct pathological drug use.

Advances in the ability to assess neuroadaptations in human patient populations will provide exciting opportunities to test the translational potential of the preclinical work

\section{REFERENCES}

Abood, M. E., Sauss, C., Fan, F., Tilton, C. L., and Martin, B. R. (1993). Development of behavioral tolerance to $\triangle 9$-THC without alteration of cannabinoid receptor binding or mRNA levels in whole brain. Pharmacol. Biochem. Behav. 46, 575-579. doi: 10.1016/0091-3057(93)90546-6

Adermark, L., Jonsson, S., Ericson, M., and Söderpalm, B. (2011). Intermittent ethanol consumption depresses endocannabinoid-signaling in the dorsolateral striatum of rat. Neuropharmacology 61, 1160-1165. doi: 10.1016/j.neuropharm. 2011.01.014

Adrover, M. F., Shin, J. H., and Alvarez, V. A. (2014). Glutamate and dopamine transmission from midbrain dopamine neurons share similar release properties but are differentially affected by cocaine. J. Neurosci. 34, 3183-3192. doi: 10 . 1523/JNEUROSCI.4958-13.2014

Ago, Y., Araki, R., Yano, K., Hiramatsu, N., Kawasaki, T., Chaki, S., et al. (2011). Activation of metabotropic glutamate $2 / 3$ receptors attenuates methamphetamine-induced hyperlocomotion and increase in prefrontal serotonergic neurotransmission. Psychopharmacology (Berl) 217, 443-452. doi: $10.1007 / \mathrm{s} 00213-011-2295-3$ highlighted here. For example, the increasing availability of PET ligands suitable for human testing will allow interrogation of drug-induced changes in receptor availability that could confirm preclinical observations of reduced presynaptic GPCR expression following repeated drug exposure without relying on the use of postmortem brain samples. In addition, methods such as magnetic resonance spectroscopy that can be used to study neurotransmitter dynamics in humans create the opportunity to assess the impact of long-term drug abuse on glutamate transmission and to test the ability of clinical drug candidates that target presynaptic GPCRs to modulate glutamate transmission in the addicted brain (Hillmer et al., 2015; Volkow et al., 2015). Ultimately, variables such as the abused $\operatorname{drug}(\mathrm{s})$ and history of drug taking will likely play a role in the efficacy of pharmacological interventions targeting presynaptic GPCRs. When designing clinical trials, it will be important to consider how the temporal relationship of the experimental intervention to drug taking (current or after short or prolonged abstinence) affects efficacy, and how time-dependent adaptations in receptor expression and function may impact the ability of novel drugs to reduce drug taking or seeking behaviors.

\section{AUTHOR CONTRIBUTIONS}

KAJ and DML both conceived of idea and plan for the manuscript, and both participated in manuscript writing and editing. KAJ created the figures and tables.

\section{ACKNOWLEDGMENTS}

This article was supported by funding from the Division of Intramural Clinical and Biological Research of the National Institute on Alcohol Abuse and Alcoholism, National Institutes of Health, project number ZIA AA000416, and a Postdoctoral Research Associate Fellowship from the National Institute of General Medical Sciences (to KAJ.). We thank Dr. David Kupferschmidt for comments on the manuscript.

Alvarez-Jaimes, L., Polis, I., and Parsons, L. H. (2008). Attenuation of cue-induced heroin-seeking behavior by cannabinoid $\mathrm{CB} 1$ antagonist infusions into the nucleus accumbens core and prefrontal cortex, but not basolateral amygdala. Neuropsychopharmacology 33, 2483-2493. doi: 10.1038/sj.npp. 1301630

Álvaro-Bartolomé, M., and García-Sevilla, J. A. (2013). Dysregulation of cannabinoid CB1 receptor and associated signaling networks in brains of cocaine addicts and cocaine-treated rodents. Neuroscience 247, 294-308. doi: 10.1016/j.neuroscience.2013.05.035

American Psychiatric Association. (2013). Diagnostic and Statistical Manual of Mental Disorders. (5th Edn.) Washington, DC: American Psychiatric Publishing.

Anwyl, R. (1999). Metabotropic glutamate receptors: electrophysiological properties and role in plasticity. Brain Res. Rev. 29, 83-120. doi: 10.1016/s01650173(98)00050-2

Arndt, D. L., Arnold, J. C., and Cain, M. E. (2014). The effects of mGluR2/3 activation on acute and repeated amphetamine-induced locomotor activity in differentially reared male rats. Exp. Clin. Psychopharmacol. 22, 257-265. doi: 10.1037/a0035273 
Atwood, B. K., Kupferschmidt, D. A., and Lovinger, D. M. (2014a). Opioids induce dissociable forms of long-term depression of excitatory inputs to the dorsal striatum. Nat. Neurosci. 17, 540-548. doi: 10.1038/nn.3652

Atwood, B. K., Lovinger, D. M., and Mathur, B. N. (2014b). Presynaptic long-term depression mediated by $\mathrm{G}_{\mathrm{i} / \mathrm{o}}$-coupled receptors. Trends Neurosci. 37, 663-673. doi: 10.1016/j.tins.2014.07.010

Augier, E., Dulman, R. S., Rauffenbart, C., Augier, G., Cross, A. J., and Heilig, M. (2016). The mGluR2 positive allosteric modulator, AZD8529 and cue-induced relapse to alcohol seeking in rats. Neuropsychopharmacology 41, 2932-2940. doi: 10.1038/npp.2016.107

Azizi, P., Haghparast, A., and Hassanpour-Ezatti, M. (2009). Effects of $\mathrm{CB} 1$ receptor antagonist within the nucleus accumbens on the acquisition and expression of morphine-induced conditioned place preference in morphinesensitized rats. Behav. Brain Res. 197, 119-124. doi: 10.1016/j.bbr.2008. 08.009

Baik, J. H. (2013). Dopamine signaling in reward-related behaviors. Front. Neural Circuits 7:152. doi: 10.3389/fncir.2013.00152

Baker, D. A., McFarland, K., Lake, R. W., Shen, H., Tang, X. C., Toda, S., et al. (2003). Neuroadaptations in cystine-glutamate exchange underlie cocaine relapse. Nat. Neurosci. 6, 743-749. doi: 10.1038/nn1069

Baptista, M. A., Martin-Fardon, R., and Weiss, F. (2004). Preferential effects of the metabotropic glutamate $2 / 3$ receptor agonist LY379268 on conditioned reinstatement versus primary reinforcement: comparison between cocaine and a potent conventional reinforcer. J. Neurosci. 24, 4723-4727. doi: 10. 1523/JNEUROSCI.0176-04.2004

Bauzo, R. M., Kimmel, H. L., and Howell, L. L. (2009). Interactions between the mGluR2/3 agonist, LY379268 and cocaine on in vivo neurochemistry and behavior in squirrel monkeys. Pharmacol. Biochem. Behav. 94, 204-210. doi: 10. 1016/j.pbb.2009.08.011

Beaulieu, J. M., and Gainetdinov, R. R. (2011). The physiology, signaling and pharmacology of dopamine receptors. Pharmacol. Rev. 63, 182-217. doi: 10. 1124/pr.110.002642

Belin-Rauscent, A., Fouyssac, M., Bonci, A., and Belin, D. (2016). How preclinical models evolved to resemble the diagnostic criteria of drug addiction. Biol. Psychiatry 79, 39-46. doi: 10.1016/j.biopsych.2015.01.004

Bello, E. P., Mateo, Y., Gelman, D. M., Noain, D., Shin, J. H., Low, M. J., et al. (2011). Cocaine supersensitivity and enhanced motivation for reward in mice lacking dopamine $\mathrm{D}_{2}$ autoreceptors. Nat. Neurosci. 14, 1033-1038. doi: 10. 1038/nn.2862

Benwell, M. E., and Balfour, D. J. (1997). Regional variation in the effects of nicotine on catecholamine overflow in rat brain. Eur. J. Pharmacol. 325, 13-20. doi: 10.1016/s0014-2999(97)00101-5

Beveridge, T. J., Smith, H. R., Nader, M. A., and Porrino, L. J. (2011). Group II metabotropic glutamate receptors in the striatum of non-human primates: dysregulation following chronic cocaine self-administration. Neurosci. Lett. 496, 15-19. doi: 10.1016/j.neulet.2011.03.077

Beyer, C. E., and Steketee, J. D. (2002). Cocaine sensitization: modulation by dopamine $\mathrm{D}_{2}$ receptors. Cereb. Cortex 12, 526-535. doi: 10.1093/cercor/12. 5.526

Biala, G., Budzynska, B., and Staniak, N. (2009). Effects of rimonabant on the reinstatement of nicotine-conditioned place preference by drug priming in rats. Behav. Brain Res. 202, 260-265. doi: 10.1016/j.bbr.2009.03.042

Bjorklund, A., and Dunnett, S. B. (2007). Dopamine neuron systems in the brain: an update. Trends Neurosci. 30, 194-202. doi: 10.1016/j.tins.2007.03.006

Blanco, E., Pavon, F. J., Palomino, A., Luque-Rojas, M. J., Serrano, A., Rivera, P., et al. (2014). Cocaine-induced behavioral sensitization is associated with changes in the expression of endocannabinoid and glutamatergic signaling systems in the mouse prefrontal cortex. Int. J. Neuropsychopharmacol. 18:pyu024. doi: 10.1093/ijnp/pyu024

Bossert, J. M., Liu, S. Y., Lu, L., and Shaham, Y. (2004). A role of ventral tegmental area glutamate in contextual cue-induced relapse to heroin seeking. J. Neurosci. 24, 10726-10730. doi: 10.1523/JNEUROSCI.3207-04.2004

Bossert, J. M., Poles, G. C., Sheffler-Collins, S. I., and Ghitza, U. E. (2006). The mGluR2/3 agonist LY379268 attenuates context- and discrete cue-induced reinstatement of sucrose seeking but not sucrose self-administration in rats. Behav. Brain Res. 173, 148-152. doi: 10.1016/j.bbr.2006.06.008

Braida, D., Pozzi, M., Cavallini, R., and Sala, M. (2001). Conditioned place preference induced by the cannabinoid agonist CP 55,940: interaction with the opioid system. Neuroscience 104, 923-926. doi: 10.1016/s0306-4522(01) 00210-x

Breivogel, C. S., Childers, S. R., Deadwyler, S. A., Hampson, R. E., Vogt, L. J., and Sim-Selley, L. J. (1999). Chronic $\Delta^{9}$-tetrahydrocannabinol treatment produces a time-dependent loss of cannabinoid receptors and cannabinoid receptoractivated G proteins in rat brain. J. Neurochem. 73, 2447-2459. doi: 10.1046/j. 1471-4159.1999.0732447.x

Brennan, K. A., Carati, C., Lea, R. A., Fitzmaurice, P. S., and Schenk, S. (2009). Effect of $\mathrm{D}_{1}$-like and D2-like receptor antagonists on methamphetamine and 3,4-methylenedioxymethamphetamine self-administration in rats. Behav. Pharmacol. 20, 688-694. doi: 10.1097/FBP.0b013e3283 $33 \mathrm{a} 28 \mathrm{~d}$

Britton, D. R., Curzon, P., Mackenzie, R. G., Kebabian, J. W., Williams, J. E., and Kerkman, D. (1991). Evidence for involvement of both D1 and D2 receptors in maintaining cocaine self-administration. Pharmacol. Biochem. Behav. 39, 911-915. doi: 10.1016/0091-3057(91)90052-4

Brown, Z. J., Kupferschmidt, D. A., and Erb, S. (2012). Reinstatement of cocaine seeking in rats by the pharmacological stressors, corticotropin-releasing factor and yohimbine: role for D1/5 dopamine receptors. Psychopharmacology (Berl) 224, 431-440. doi: 10.1007/s00213-012-2772-3

Budney, A. J., Hughes, J. R., Moore, B. A., and Novy, P. L. (2001). Marijuana abstinence effects in marijuana smokers maintained in their home environment. Arch. Gen. Psychiatry 58, 917-924. doi: 10.1001/archpsyc. 58.10 .917

Cabib, S., Castellano, C., Cestari, V., Filibeck, U., and Puglisi-Allegra, S. (1991). D1 and D2 receptor antagonists differently affect cocaine-induced locomotor hyperactivity in the mouse. Psychopharmacology (Berl) 105, 335-339. doi: 10. $1007 /$ bf02244427

Caillé, S., Alvarez-Jaimes, L., Polis, I., Stouffer, D. G., and Parsons, L. H. (2007). Specific alterations of extracellular endocannabinoid levels in the nucleus accumbens by ethanol, heroin and cocaine self-administration. J. Neurosci. 27, 3695-3702. doi: 10.1523/JNEUROSCI.4403-06.2007

Caillé, S., and Parsons, L. H. (2006). Cannabinoid modulation of opiate reinforcement through the ventral striatopallidal pathway. Neuropsychopharmacology 31, 804-813. doi: 10.1038/sj.npp.1300848

Caine, S. B., and Koob, G. F. (1994). Effects of dopamine D-1 and D-2 antagonists on cocaine self-administration under different schedules of reinforcement in the rat. J. Pharmacol. Exp. Ther. 270, 209-218.

Caine, S. B., Negus, S. S., Mello, N. K., Patel, S., Bristow, L., Kulagowski, J., et al. (2002). Role of dopamine D2-like receptors in cocaine self-administration: studies with D2 receptor mutant mice and novel D2 receptor antagonists. J. Neurosci. 22, 2977-2988.

Caine, S. B., Thomsen, M., Gabriel, K. I., Berkowitz, J. S., Gold, L. H., Koob, G. F., et al. (2007). Lack of self-administration of cocaine in dopamine $D_{1}$ receptor knock-out mice. J. Neurosci. 27, 13140-13150. doi: 10.1523/JNEUROSCI.228407.2007

Cannella, N., Halbout, B., Uhrig, S., Evrard, L., Corsi, M., Corti, C., et al. (2013). The mGluR2/3 agonist LY379268 induced anti-reinstatement effects in rats exhibiting addiction-like behavior. Neuropsychopharmacology 38, 2048-2056. doi: 10.1038/npp.2013.106

Caprioli, D., Venniro, M., Zeric, T., Li, X., Adhikary, S., Madangopal, R., et al. (2015). Effect of the novel positive allosteric modulator of metabotropic glutamate receptor 2 AZD8529 on incubation of methamphetamine craving after prolonged voluntary abstinence in a rat model. Biol. Psychiatry 78, 463-473. doi: 10.1016/j.biopsych.2015.02.018

Cartmell, J., and Schoepp, D. D. (2000). Regulation of neurotransmitter release by metabotropic glutamate receptors. J. Neurochem. 75, 889-907. doi: 10.1046/j. 1471-4159.2000.0750889.x

Ceccarini, J., Kuepper, R., Kemels, D., van Os, J., Henquet, C., and Van Laere, K. (2015). $\left[{ }^{18} \mathrm{~F}\right] \mathrm{MK}-9470$ PET measurement of cannabinoid CB1 receptor availability in chronic cannabis users. Addict. Biol. 20, 357-367. doi: 10 1111/adb.12116

Centonze, D., Rossi, S., De Chiara, V., Prosperetti, C., Battista, N., Bernardi, G., et al. (2007). Chronic cocaine sensitizes striatal GABAergic synapses to the stimulation of cannabinoid CB1 receptors. Eur. J. Neurosci. 25, 1631-1640. doi: $10.1111 /$ j.1460-9568.2007.05433.x

Cervo, L., and Samanin, R. (1995). Effects of dopaminergic and glutamatergic receptor antagonists on the acquisition and expression of cocaine conditioning 
place preference. Brain Res. 673, 242-250. doi: 10.1016/0006-8993(94) 01420-m

Chandra, R., Lenz, J. D., Gancarz, A. M., Chaudhury, D., Schroeder, G. L., Han, M. H., et al. (2013). Optogenetic inhibition of D1R containing nucleus accumbens neurons alters cocaine-mediated regulation of Tiam1. Front. Mol. Neurosci. 6:13. doi: 10.3389/fnmol.2013.00013

Chaperon, F., Soubrié, P., Puech, A. J., and Thiébot, M. H. (1998). Involvement of central cannabinoid (CB1) receptors in the establishment of place conditioning in rats. Psychopharmacology (Berl) 135, 324-332. doi: 10.1007/s00213 0050518

Cheer, J. F., Kendall, D. A., and Marsden, C. A. (2000). Cannabinoid receptors and reward in the rat: a conditioned place preference study. Psychopharmacology (Berl) 151, 25-30. doi: 10.1007/s002130000481

Cheer, J. F., Wassum, K. M., Sombers, L. A., Heien, M. L., Ariansen, J. L., Aragona, B. J., et al. (2007). Phasic dopamine release evoked by abused substances requires cannabinoid receptor activation. J. Neurosci. 27, 791-795. doi: 10.1523/JNEUROSCI.4152-06.2007

Chevaleyre, V., and Castillo, P. E. (2003). Heterosynaptic LTD of hippocampal GABAergic synapses: a novel role of endocannabinoids in regulating excitability. Neuron 38, 461-472. doi: 10.1016/S0896-6273(03) 00235-6

Chevaleyre, V., Takahashi, K. A., and Castillo, P. E. (2006). Endocannabinoidmediated synaptic plasticity in the CNS. Annu. Rev. Neurosci. 29, 37-76. doi: 10. 1146/annurev.neuro.29.051605.112834

Cohen, C., Perrault, G., Griebel, G., and Soubrié, P. (2005). Nicotine-associated cues maintain nicotine-seeking behavior in rats several weeks after nicotine withdrawal: reversal by the cannabinoid (CB1) receptor antagonist, rimonabant (SR141716). Neuropsychopharmacology 30, 145-155. doi: 10.1038/sj.npp. 1300541

Cohen, C., Perrault, G., Voltz, C., Steinberg, R., and Soubrié, P. (2002). SR141716, a central cannabinoid (CB1) receptor antagonist, blocks the motivational and dopamine-releasing effects of nicotine in rats. Behav. Pharmacol. 13, 451-463. doi: 10.1097/00008877-200209000-00018

Compton, D. R., Dewey, W. L., and Martin, B. R. (1990). Cannabis dependence and tolerance production. Adv. Alcohol Subst. Abuse 9, 129-147. doi: 10. 1300/J251v09n01_08

Conn, P. J., Lindsley, C. W., Meiler, J., and Niswender, C. M. (2014). Opportunities and challenges in the discovery of allosteric modulators of GPCRs for treating CNS disorders. Nat. Rev. Drug Discov. 13, 692-708. doi: 10.1038/nrd4308

Cook, S. A., Lowe, J. A., and Martin, B. R. (1998). CB1 receptor antagonist precipitates withdrawal in mice exposed to $\Delta^{9}$-tetrahydrocannabinol. J. Pharmacol. Exp. Ther. 285, 1150-1156.

Corrigall, W. A., and Coen, K. M. (1991a). Cocaine self-administration is increased by both D1 and D2 dopamine antagonists. Pharmacol. Biochem. Behav. 39, 799-802. doi: 10.1016/0091-3057(91)90168-2

Corrigall, W. A., and Coen, K. M. (1991b). Selective dopamine antagonists reduce nicotine self-administration. Psychopharmacology (Berl) 104, 171-176. doi: 10. 1007/bf02244174

Cossu, G., Ledent, C., Fattore, L., Imperato, A., Böhme, G. A., Parmentier, M., et al. (2001). Cannabinoid CB1 receptor knockout mice fail to self-administer morphine but not other drugs of abuse. Behav. Brain Res. 118, 61-65. doi: 10. 1016/s0166-4328(00)00311-9

Counotte, D. S., Goriounova, N. A., Li, K. W., Loos, M., van der Schors, R. C., Schetters, D., et al. (2011). Lasting synaptic changes underlie attention deficits caused by nicotine exposure during adolescence. Nat. Neurosci. 14, 417-419. doi: $10.1038 / \mathrm{nn} .2770$

Covey, D. P., Wenzel, J. M., and Cheer, J. F. (2015). Cannabinoid modulation of drug reward and the implications of marijuana legalization. Brain Res. 1628, 233-243. doi: 10.1016/j.brainres.2014.11.034

Crawford, J. T., Roberts, D. C., and Beveridge, T. J. (2013). The group II metabotropic glutamate receptor agonist, LY379268, decreases methamphetamine self-administration in rats. Drug Alcohol Depend. 132, 414-419. doi: 10.1016/j.drugalcdep.2013.07.024

Cross, A. J. (2013). AZD8529-an mGluR2 positive allosteric modulator for the treatment of schizophrenia. Neuropsychopharmacology 38:S25.

de Bruin, N. M., Lange, J. H., Kruse, C. G., Herremans, A. H., Schoffelmeer, A. N., van Drimmelen, M., et al. (2011). SLV330, a cannabinoid $\mathrm{CB}_{1}$ receptor antagonist, attenuates ethanol and nicotine seeking and improves inhibitory response control in rats. Behav. Brain Res. 217, 408-415. doi: 10.1016/j.bbr. 2010.11.013

DePoy, L., Daut, R., Brigman, J. L., MacPherson, K., Crowley, N., GunduzCinar, O., et al. (2013). Chronic alcohol produces neuroadaptations to prime dorsal striatal learning. Proc. Natl. Acad. Sci. U S A 110, 14783-14788. doi: 10. 1073/pnas.1308198110

De Vries, T. J., Schoffelmeer, A. N., Binnekade, R., Raaso, H., and Vanderschuren, L. J. (2002). Relapse to cocaine- and heroin-seeking behavior mediated by dopamine D2 receptors is time-dependent and associated with behavioral sensitization. Neuropsychopharmacology 26, 18-26. doi: 10 . 1016/s0893-133x(01)00293-7

De Vries, T. J., Schoffelmeer, A. N., Binnekade, R., and Vanderschuren, L. J. (1999). Dopaminergic mechanisms mediating the incentive to seek cocaine and heroin following long-term withdrawal of IV drug self-administration. Psychopharmacology (Berl) 143, 254-260. doi: 10.1007/s002130050944

De Vries, T. J., Shaham, Y., Homberg, J. R., Crombag, H., Schuurman, K., Dieben, J., et al. (2001). A cannabinoid mechanism in relapse to cocaine seeking. Nat. Med. 7, 1151-1154. doi: 10.1038/nm1001-1151

Dhanya, R. P., Sheffler, D. J., Dahl, R., Davis, M., Lee, P. S., Yang, L., et al. (2014). Design and synthesis of systemically active metabotropic glutamate subtype- 2 and $-3\left(\mathrm{mGlu}_{2 / 3}\right)$ receptor positive allosteric modulators (PAMs): pharmacological characterization and assessment in a rat model of cocaine dependence. J. Med. Chem. 57, 4154-4172. doi: 10.1021/jm50 00563

Dhanya, R. P., Sidique, S., Sheffler, D. J., Nickols, H. H., Herath, A., Yang, L., et al. (2011). Design and synthesis of an orally active metabotropic glutamate receptor subtype-2 (mGluR2) positive allosteric modulator (PAM) that decreases cocaine self-administration in rats. J. Med. Chem. 54, 342-353. doi: $10.1021 / \mathrm{jm} 1012165$

Di Chiara, G., and Imperato, A. (1988). Drugs abused by humans preferentially increase synaptic dopamine concentrations in the mesolimbic system of freely moving rats. Proc. Natl. Acad. Sci. U S A 85, 5274-5278. doi: 10.1073/pnas.85. 14.5274

Dobbs, L. K., Kaplan, A. R., Lemos, J. C., Matsui, A., Rubinstein, M., and Alvarez, V. A. (2016). Dopamine regulation of lateral inhibition between striatal neurons gates the stimulant actions of cocaine. Neuron 90, 1100-1113. doi: 10.1016/j.neuron.2016.04.031

Dougalis, A. G., Matthews, G. A., Bishop, M. W., Brischoux, F., Kobayashi, K., and Ungless, M. A. (2012). Functional properties of dopamine neurons and co-expression of vasoactive intestinal polypeptide in the dorsal raphe nucleus and ventro-lateral periaqueductal grey. Eur. J. Neurosci. 36, 3322-3332. doi: 10. 1111/j.1460-9568.2012.08255.x

D’Souza, M. S., Liechti, M. E., Ramirez-Niño, A. M., Kuczenski, R., and Markou, A. (2011). The metabotropic glutamate $2 / 3$ receptor agonist LY379268 blocked nicotine-induced increases in nucleus accumbens shell dopamine only in the presence of a nicotine-associated context in rats. Neuropsychopharmacology 36, 2111-2124. doi: 10.1038/npp.2011.103

Dudok, B., Barna, L., Ledri, M., Szabó, S. I., Szabadits, E., Pintér, B., et al. (2015). Cell-specific STORM super-resolution imaging reveals nanoscale organization of cannabinoid signaling. Nat. Neurosci. 18, 75-86. doi: 10.1038/nn.3892

Enoch, M. A., Rosser, A. A., Zhou, Z., Mash, D. C., Yuan, Q., and Goldman, D. (2014). Expression of glutamatergic genes in healthy humans across 16 brain regions; altered expression in the hippocampus after chronic exposure to alcohol or cocaine. Genes Brain Behav. 13, 758-768. doi: 10.1111/gbb. 12179

Fang, Q., Li, F. Q., Li, Y. Q., Xue, Y. X., He, Y. Y., Liu, J. F., et al. (2011). Cannabinoid CB1 receptor antagonist rimonabant disrupts nicotine rewardassociated memory in rats. Pharmacol. Biochem. Behav. 99, 738-742. doi: 10. 1016/j.pbb.2011.06.019

Fattore, L., Spano, S., Cossu, G., Deiana, S., Fadda, P., and Fratta, W. (2005). Cannabinoid $\mathrm{CB}_{1}$ antagonist SR 141716A attenuates reinstatement of heroin self-administration in heroin-abstinent rats. Neuropharmacology 48, 1097-1104. doi: 10.1016/j.neuropharm.2005.01.022

Floran, B., Floran, L., Sierra, A., and Aceves, J. (1997). D2 receptor-mediated inhibition of GABA release by endogenous dopamine in the rat globus pallidus. Neurosci. Lett. 237, 1-4. doi: 10.1016/s0304-3940(97)00784-2

Forget, B., Coen, K. M., and Le Foll, B. (2009). Inhibition of fatty acid amide hydrolase reduces reinstatement of nicotine seeking but not break point 
for nicotine self-administration-comparison with $\mathrm{CB}_{1}$ receptor blockade. Psychopharmacology (Berl) 205, 613-624. doi: 10.1007/s00213-009-1569-5

Forget, B., Hamon, M., and Thiebot, M. H. (2005). Cannabinoid CB1 receptors are involved in motivational effects of nicotine in rats. Psychopharmacology (Berl) 181, 722-734. doi: 10.1007/s00213-005-0015-6

Fourgeaud, L., Mato, S., Bouchet, D., Hemar, A., Worley, P. F., and Manzoni, O. J. (2004). A single in vivo exposure to cocaine abolishes endocannabinoidmediated long-term depression in the nucleus accumbens. J. Neurosci. 24, 6939-6945. doi: 10.1523/JNEUROSCI.0671-04.2004

Freedland, C. S., Sharpe, A. L., Samson, H. H., and Porrino, L. J. (2001). Effects of SR141716A on ethanol and sucrose self-administration. Alcohol. Clin. Exp. Res. 25, 277-282. doi: 10.1097/00000374-200102000-00017

Fuchs, R. A., Tran-Nguyen, L. T., Weber, S. M., Khroyan, T. V., and Neisewander, J. L. (2002). Effects of 7-OH-DPAT on cocaine-seeking behavior and on re-establishment of cocaine self-administration. Pharmacol. Biochem. Behav. 72, 623-632. doi: 10.1016/s0091-3057(02)00731-1

Gamaleddin, I., Wertheim, C., Zhu, A. Z., Coen, K. M., Vemuri, K., Makryannis, A., et al. (2012). Cannabinoid receptor stimulation increases motivation for nicotine and nicotine seeking. Addict. Biol. 17, 47-61. doi: 10. $1111 / j .1369-1600.2011 .00314 . x$

Garcia-Munoz, M., Young, S. J., and Groves, P. M. (1991). Terminal excitability of the corticostriatal pathway. I. Regulation by dopamine receptor stimulation. Brain Res. 551, 195-206. doi: 10.1016/0006-8993(91)90933-m

Gardner, E. L. (2002). Addictive potential of cannabinoids: the underlying neurobiology. Chem. Phys. Lipids 121, 267-290. doi: 10.1016/s00093084(02)00162-7

Gasbarri, A., Sulli, A., and Packard, M. G. (1997). The dopaminergic mesencephalic projections to the hippocampal formation in the rat. Prog. Neuropsychopharmacol. Biol. Psychiatry 21, 1-22. doi: 10.1016/s02785846(96)00157-1

Gates, P. J., Albertella, L., and Copeland, J. (2014). The effects of cannabinoid administration on sleep: a systematic review of human studies. Sleep Med. Rev. 18, 477-487. doi: 10.1016/j.smrv.2014.02.005

Gilman, J. M., Kuster, J. K., Lee, S., Lee, M. J., Kim, B. W., Makris, N., et al. (2014). Cannabis use is quantitatively associated with nucleus accumbens and amygdala abnormalities in young adult recreational users. J. Neurosci. 34, 5529-5538. doi: 10.1523/JNEUROSCI.4745-13.2014

Glynn, G., and Ahmad, S. O. (2003). Regional variations in the physiology of the rat caudate-putamen 2. Effects of amphetamine and amphetamine induced dopamine release on basal and cortical stimulation evoked multiple unit activity. J. Neural Transm. (Vienna) 110, 461-485. doi: 10.1007/s00702-0020802-8

Goeders, N. E., and Kuhar, M. J. (1987). Chronic cocaine administration induces opposite changes in dopamine receptors in the striatum and nucleus accumbens. Alcohol Drug Res. 7, 207-216.

Goeders, N. E., and Smith, J. E. (1983). Cortical dopaminergic involvement in cocaine reinforcement. Science 221, 773-775. doi: 10.1126/science.6879176

Gremel, C. M., and Lovinger, D. M. (2016). Associative and sensorimotor corticobasal ganglia circuit roles in effects of abused drugs. Genes Brain Behav. doi: 10. 1111/gbb.12309 [Epub ahead of print].

Grueter, B. A., and Winder, D. G. (2005). Group II and III metabotropic glutamate receptors suppress excitatory synaptic transmission in the dorsolateral bed nucleus of the stria terminalis. Neuropsychopharmacology 30, 1302-1311. doi: 10.1038/sj.npp.1300672

Gueye, A. B., Pryslawsky, Y., Trigo, J. M., Poulia, N., Delis, F., Antoniou, K., et al. (2016). The CB1 neutral antagonist AM4113 retains the therapeutic efficacy of the inverse agonist rimonabant for nicotine dependence and weight loss with better psychiatric tolerability. Int. J. Neuropsychopharmacol. doi: 10 . 1093/ijnp/pyw068 [Epub ahead of print].

Hall, B. J., Slade, S., Allenby, C., Kutlu, M. G., and Levin, E. D. (2015). Neuro-anatomic mapping of dopamine D1 receptor involvement in nicotine self-administration in rats. Neuropharmacology 99, 689-695. doi: 10.1016/j. neuropharm.2015.03.005

Haney, M., Ward, A. S., Comer, S. D., Foltin, R. W., and Fischman, M. W. (1999). Abstinence symptoms following smoked marijuana in humans. Psychopharmacology (Berl) 141, 395-404. doi: 10.1007/s002130050849

Hanna, L., Ceolin, L., Lucas, S., Monn, J., Johnson, B., Collingridge, G., et al. (2013). Differentiating the roles of mGlu2 and mGlu3 receptors using LY541850, an mGlu2 agonist/mGlu3 antagonist. Neuropharmacology 66, 114-121. doi: 10.1016/j.neuropharm.2012.02.023

Hao, Y., Martin-Fardon, R., and Weiss, F. (2010). Behavioral and functional evidence of metabotropic glutamate receptor $2 / 3$ and metabotropic glutamate receptor 5 dysregulation in cocaine-escalated rats: factor in the transition to dependence. Biol. Psychiatry 68, 240-248. doi: 10.1016/j.biopsych.2010. 02.011

Harvey, J., and Lacey, M. G. (1996). Endogenous and exogenous dopamine depress EPSCs in rat nucleus accumbens in vitro via D1 receptors activation. J. Physiol. 492, 143-154. doi: 10.1113/jphysiol.1996.sp021296

Hashemizadeh, S., Sardari, M., and Rezayof, A. (2014). Basolateral amygdala CB1 cannabinoid receptors mediate nicotine-induced place preference. Prog. Neuropsychopharmacol. Biol. Psychiatry 51, 65-71. doi: 10.1016/j.pnpbp.2014. 01.010

Hasin, D. S., O’Brien, C. P., Auriacombe, M., Borges, G., Bucholz, K., Budney, A., et al. (2013). DSM-5 criteria for substance use disorders: recommendations and rationale. Am. J. Psychiatry 170, 834-851. doi: 10.1176/appi.ajp.2013. 12060782

Heinbockel, T., Brager, D. H., Reich, C. G., Zhao, J., Muralidharan, S., Alger, B. E., et al. (2005). Endocannabinoid signaling dynamics probed with optical tools. J. Neurosci. 25, 9449-9459. doi: 10.1523/JNEUROSCI.2078-05.2005

Herlitze, S., Garcia, D. E., Mackie, K., Hille, B., Scheuer, T., and Catterall, W. A. (1996). Modulation of $\mathrm{Ca}^{2+}$ channels by G-protein $\beta \gamma$ subunits. Nature 380, 258-262. doi: $10.1038 / 381172 \mathrm{~d} 0$

Hernandez, G., Oleson, E. B., Gentry, R. N., Abbas, Z., Bernstein, D. L., Arvanitogiannis, A., et al. (2014). Endocannabinoids promote cocaine-induced impulsivity and its rapid dopaminergic correlates. Biol. Psychiatry 75, 487-498. doi: 10.1016/j.biopsych.2013.09.005

Hikida, T., Kimura, K., Wada, N., Funabiki, K., and Nakanishi, S. (2010). Distinct roles of synaptic transmission in direct and indirect striatal pathways to reward and aversive behavior. Neuron 66, 896-907. doi: 10.1016/j.neuron.2010. 05.011

Hillmer, A. T., Mason, G. F., Fucito, L. M., O’Malley, S. S., and Cosgrove, K. P. (2015). How imaging glutamate, $\gamma$-aminobutyric acid and dopamine can inform the clinical treatment of alcohol dependence and withdrawal. Alcohol. Clin. Exp. Res. 39, 2268-2282. doi: 10.1111/acer.12893

Hiyoshi, T., Marumo, T., Hikichi, H., Tomishima, Y., Urabe, H., Tamita, T., et al. (2014). Neurophysiologic and antipsychotic profiles of TASP0433864, a novel positive allosteric modulator of metabotropic glutamate 2 receptor. J. Pharmacol. Exp. Ther. 351, 642-653. doi: 10.1124/jpet.114. 218651

Hoffman, A. F., and Lupica, C. R. (2013). Synaptic targets of $\Delta^{9}$-tetrahydrocannabinol in the central nervous system. Cold Spring Harb. Perspect. Med. 3:a012237. doi: 10.1101/cshperspect.a012237

Houchi, H., Babovic, D., Pierrefiche, O., Ledent, C., Daoust, M., and Naassila, M. (2005). $\mathrm{CB}_{1}$ receptor knockout mice display reduced ethanol-induced conditioned place preference and increased striatal dopamine D2 receptors. Neuropsychopharmacology 30, 339-349. doi: 10.1038/sj.npp.1300568

Huang, C. C., and Hsu, K. S. (2008). The role of NMDA receptors in regulating group II metabotropic glutamate receptor-mediated long-term depression in rat medial prefrontal cortex. Neuropharmacology 54, 1071-1078. doi: 10.1016/j. neuropharm.2008.02.013

Huang, Y. C., Wang, S. J., Chiou, L. C., and Gean, P. W. (2003). Mediation of amphetamine-induced long-term depression of synaptic transmission by CB1 cannabinoid receptors in the rat amygdala. J. Neurosci. 23, 10311-10320.

Huang, C. C., Yang, P. C., Lin, H. J., and Hsu, K. S. (2007). Repeated cocaine administration impairs group II metabotropic glutamate receptormediated long-term depression in rat medial prefrontal cortex. J. Neurosci. 27, 2958-2968. doi: 10.1523/JNEUROSCI.4247-06.2007

Hubner, C. B., and Moreton, J. E. (1991). Effects of selective D1 and D2 dopamine antagonists on cocaine self-administration in the rat. Psychopharmacology (Berl) 105, 151-156. doi: 10.1007/bf02244301

Hummel, M., and Unterwald, E. M. (2002). D1 dopamine receptor: a putative neurochemical and behavioral link to cocaine action. J. Cell. Physiol. 191, 17-27. doi: $10.1002 /$ jcp. 10078

Ikeda, S. R. (1996). Voltage-dependent modulation of N-type calcium channels by G-protein $\beta \gamma$ subunits. Nature 380, 255-258. doi: 10.1038/380255a0 
Jin, X., Semenova, S., Yang, L., Ardecky, R., Sheffler, D. J., Dahl, R., et al. (2010). The mGluR2 positive allosteric modulator BINA decreases cocaine self-administration and cue-induced cocaine-seeking and counteracts cocaine-induced enhancement of brain reward function in rats. Neuropsychopharmacology 35, 2021-2036. doi: 10.1038/npp.2010.82

Jin, L. E., Wang, M., Yang, S. T., Yang, Y., Galvin, V. C., Lightbourne, T. C., et al. (2016). mGluR2/3 mechanisms in primate dorsolateral prefrontal cortex: evidence for both presynaptic and postsynaptic actions. Mol. Psychiatry doi: 10 . 1038/mp.2016.129 [Epub ahead of print].

Jing, L., Qiu, Y., Zhang, Y., and Li, J. X. (2014). Effects of the cannabinoid $\mathrm{CB}_{1}$ receptor allosteric modulator ORG 27569 on reinstatement of cocaineand methamphetamine-seeking behavior in rats. Drug Alcohol Depend. 143, 251-256. doi: 10.1016/j.drugalcdep.2014.08.004

Johnson, S. W., and North, R. A. (1992). Opioids excite dopamine neurons by hyperpolarization of local interneurons. J. Neurosci. 12, 483-488.

Justinova, Z., Goldberg, S. R., Heishman, S. J., and Tanda, G. (2005). Selfadministration of cannabinoids by experimental animals and human marijuana smokers. Pharmacol. Biochem. Behav. 81, 285-299. doi: 10.1016/j.pbb.2005.01. 026

Justinova, Z., Le Foll, B., Redhi, G. H., Markou, A., and Goldberg, S. R. (2016). Differential effects of the metabotropic glutamate $2 / 3$ receptor agonist LY379268 on nicotine versus cocaine self-administration and relapse in squirrel monkeys. Psychopharmacology (Berl) 233, 1791-1800. doi: 10.1007/s00213015-3994-y

Justinova, Z., Munzar, P., Panlilio, L. V., Yasar, S., Redhi, G. H., Tanda, G., et al. (2008). Blockade of THC-seeking behavior and relapse in monkeys by the cannabinoid $\mathrm{CB}_{1}$-receptor antagonist rimonabant. Neuropsychopharmacology 33, 2870-2877. doi: 10.1038/npp.2008.21

Justinova, Z., Panlilio, L. V., and Goldberg, S. R. (2009). Drug addiction. Curr. Top. Behav. Neurosci. 1, 309-346. doi: 10.1007/978-3-540-88955-7_13

Justinova, Z., Panlilio, L. V., Secci, M. E., Redhi, G. H., Schindler, C. W., Cross, A. J., et al. (2015). The novel metabotropic glutamate receptor 2 positive allosteric modulator, AZD8529, decreases nicotine self-administration and relapse in squirrel monkeys. Biol. Psychiatry 78, 452-462. doi: 10.1016/j. biopsych.2015.01.014

Justinova, Z., Tanda, G., Redhi, G. H., and Goldberg, S. R. (2003). Selfadministration of $\Delta^{9}$-tetrahydrocannabinol (THC) by drug naive squirrel monkeys. Psychopharmacology (Berl) 169, 135-140. doi: 10.1007/s00213-0031484-0

Kahn, L., Alonso, G., Robbe, D., Bockaert, J., and Manzoni, O. J. (2001). Group 2 metabotropic glutamate receptors induced long term depression in mouse striatal slices. Neurosci. Lett. 316, 178-182. doi: 10.1016/s0304-3940(01) 02397-7

Kalivas, P. W. (1995). Interactions between dopamine and excitatory amino acids in behavioral sensitization to psychostimulants. Drug Alcohol Depend. 37, 95-100. doi: 10.1016/0376-8716(94)01063-q

Kalivas, P. W. (2009). The glutamate homeostasis hypothesis of addiction. Nat. Rev. Neurosci. 10, 561-572. doi: 10.1038/nrn2515

Karkhanis, A. N., Beveridge, T. J., Blough, B. E., Jones, S. R., and Ferris, M. J. (2016). The individual and combined effects of phenmetrazine and mgluR2/3 agonist LY379268 on the motivation to self-administer cocaine. Drug Alcohol Depend. 166, 51-60. doi: 10.1016/j.drugalcdep.2016.06.020

Karlsson, R. M., Hefner, K. R., Sibley, D. R., and Holmes, A. (2008). Comparison of dopamine D1 and D5 receptor knockout mice for cocaine locomotor sensitization. Psychopharmacology (Berl) 200, 117-127. doi: 10.1007/s00213008-1165-0

Kasanetz, F., Deroche-Gamonet, V., Berson, N., Balado, E., Lafourcade, M., Manzoni, O., et al. (2010). Transition to addiction is associated with a persistent impairment in synaptic plasticity. Science 328, 1709-1712. doi: 10.1126/science. 1187801

Kasanetz, F., Lafourcade, M., Deroche-Gamonet, V., Revest, J. M., Berson, N., Balado, E., et al. (2013). Prefrontal synaptic markers of cocaine addiction-like behavior in rats. Mol. Psychiatry 18, 729-737. doi: 10.1038/mp.2012.59

Kaur, R., Ambwani, S. R., and Singh, S. (2016). Endocannabinoid system: a multi-facet therapeutic target. Curr. Clin. Pharmacol. 11, 110-117. doi: 10. 2174/1574884711666160418105339

Khroyan, T. V., Barrett-Larimore, R. L., Rowlett, J. K., and Spealman, R. D. (2000). Dopamine D1- and D2-like receptor mechanisms in relapse to cocaine-seeking behavior: effects of selective antagonists and agonists. J. Pharmacol. Exp. Ther. 294, 680-687.

Kim, J. H., Austin, J. D., Tanabe, L., Creekmore, E., and Vezina, P. (2005), Activation of group II mGlu receptors blocks the enhanced drug taking induced by previous exposure to amphetamine. Eur. J. Neurosci. 21, 295-300. doi: 10. $1111 / \mathrm{j} .1460-9568.2004 .03822 . x$

Kim, J. H., and Vezina, P. (2002). The mGlu2/3 receptor agonist LY379268 blocks the expression of locomotor sensitization by amphetamine. Pharmacol. Biochem. Behav. 73, 333-337. doi: 10.1016/s0091-3057(02)00827-4

Kirilly, E., Gonda, X., and Bagdy, G. (2012). CB1 receptor antagonists: new discoveries leading to new perspectives. Acta Physiol. (Oxf.) 205, 41-60. doi: 10. $1111 / j .1748-1716.2012 .02402 . x$

Kodas, E., Cohen, C., Louis, C., and Griebel, G. (2007). Cortico-limbic circuitry for conditioned nicotine-seeking behavior in rats involves endocannabinoid signaling. Psychopharmacology (Berl) 194, 161-171. doi: 10.1007/s00213-0070813-0

Koob, G. F., and Volkow, N. D. (2016). Neurobiology of addiction: a neurocircuitry analysis. Lancet Psychiatry 3, 760-773. doi: 10.1016/S22150366(16)00104-8

Kretz, R., Shapiro, E., Bailey, C. H., Chen, M., and Kandel, E. R. (1986). Presynaptic inhibition produced by an identified presynaptic inhibitory neuron. II. Presynaptic conductance changes caused by histamine. J. Neurophysiol. 55, 131-146.

Kufahl, P. R., Martin-Fardon, R., and Weiss, F. (2011). Enhanced sensitivity to attenuation of conditioned reinstatement by the mGluR $2 / 3$ agonist LY379268 and increased functional activity of mGluR $2 / 3$ in rats with a history of ethanol dependence. Neuropsychopharmacology 36, 2762-2773. doi: 10. 1038/npp.2011.174

Kufahl, P. R., Watterson, L. R., Nemirovsky, N. E., Hood, L. E., Villa, A., Halstengard, C., et al. (2013). Attenuation of methamphetamine seeking by the mGluR2/3 agonist LY379268 in rats with histories of restricted and escalated self-administration. Neuropharmacology 66, 290-301. doi: 10.1016/j. neuropharm.2012.05.037

Kupchik, Y. M., Barchad-Avitzur, O., Wess, J., Ben-Chaim, Y., Parnas, I., and Parnas, H. (2011). A novel fast mechanism for GPCR-mediated signal transduction-control of neurotransmitter release. J. Cell Biol. 192, 137-151. doi: $10.1083 /$ jcb. 201007053

Kupchik, Y. M., Rashkovan, G., Ohana, L., Keren-Raifman, T., Dascal, N., Parnas, H., et al. (2008). Molecular mechanisms that control initiation and termination of physiological depolarization-evoked transmitter release. Proc. Natl. Acad. Sci. U S A 105, 4435-4440. doi: 10.1073/pnas.07085 40105

Kupferschmidt, D. A., and Lovinger, D. M. (2015). Inhibition of presynaptic calcium transients in cortical inputs to the dorsolateral striatum by metabotropic $\mathrm{GABA}_{B}$ and mGlu2/3 receptors. J. Physiol. 593, 2295-2310. doi: 10.1113/JP270045

Kuribara, H., and Uchihashi, Y. (1993). Dopamine antagonists can inhibit methamphetamine sensitization, but not cocaine sensitization, when assessed by ambulatory activity in mice. J. Pharm. Pharmacol. 45, 1042-1045. doi: 10. 1111/j.2042-7158.1993.tb07177.x

Kutlu, M. G., Burke, D., Slade, S., Hall, B. J., Rose, J. E., and Levin, E. D. (2013). Role of insular cortex $\mathrm{D}_{1}$ and $\mathrm{D}_{2}$ dopamine receptors in nicotine self-administration in rats. Behav. Brain Res. 256, 273-278. doi: 10.1016/j.bbr.2013.08.005

Lammel, S., Hetzel, A., Häckel, O., Jones, I., Liss, B., and Roeper, J. (2008). Unique properties of mesoprefrontal neurons within a dual mesocorticolimbic dopamine system. Neuron 57, 760-773. doi: 10.1016/j.neuron.2008.01.022

Latek, D., Modzelewska, A., Trzaskowski, B., Palczewski, K., and Filipek, S. (2012). G protein-coupled receptors-recent advances. Acta Biochim. Pol. 59, 515-529.

Le Foll, B., and Goldberg, S. R. (2004). Rimonabant, a CB1 antagonist, blocks nicotine-conditioned place preferences. Neuroreport 15, 2139-2143. doi: 10. 1097/00001756-200409150-00028

Lesscher, H. M., Hoogveld, E., Burbach, J. P., van Ree, J. M., and Gerrits, M. A. (2005). Endogenous cannabinoids are not involved in cocaine reinforcement and development of cocaine-induced behavioural sensitization. Eur. Neuropsychopharmacol. $\quad 15, \quad 31-37 . \quad$ doi: 10.1016/j.euroneuro.2004. 04.003

Li, X., D’Souza, M. S., Niño, A. M., Doherty, J., Cross, A., and Markou, A. (2016). Attenuation of nicotine-taking and nicotine-seeking behavior by the 
mGlu2 receptor positive allosteric modulators AZD8418 and AZD8529 in rats. Psychopharmacology (Berl) 233, 1801-1814. doi: 10.1007/s00213-016-4220-2

Li, X., Hoffman, A. F., Peng, X. Q., Lupica, C. R., Gardner, E. L., and Xi, Z. X. (2009). Attenuation of basal and cocaine-enhanced locomotion and nucleus accumbens dopamine in cannabinoid CB1-receptor-knockout mice. Psychopharmacology (Berl) 204, 1-11. doi: 10.1007/s00213-008$1432-0$

Li, X., Xi, Z. X., and Markou, A. (2013). Metabotropic glutamate 7 (mGlu7) receptor: a target for medication development for the treatment of cocaine dependence. Neuropharmacology 66, 12-23. doi: 10.1016/j.neuropharm.2012. 04.010

Liechti, M. E., Lhuillier, L., Kaupmann, K., and Markou, A. (2007). Metabotropic glutamate $2 / 3$ receptors in the ventral tegmental area and the nucleus accumbens shell are involved in behaviors relating to nicotine dependence. J. Neurosci. 27, 9077-9085. doi: 10.1523/JNEUROSCI.1766-07.2007

Liu, X., Jernigen, C., Gharib, M., Booth, S., Caggiula, A. R., and Sved, A. F. (2010). Effects of dopamine antagonists on drug cue-induced reinstatement of nicotine-seeking behavior in rats. Behav. Pharmacol. 21, 153-160. doi: 10. 1097/FBP.0b013e328337be95

Lovinger, D. M., and McCool, B. A. (1995). Metabotropic glutamate receptormediated presynaptic depression at corticostriatal synapses involves mGLuR2 or 3. J. Neurophysiol. 73, 1076-1083.

$\mathrm{Lu}, \mathrm{H}$. C., and Mackie, K. (2016). An introduction to the endogenous cannabinoid system. Biol. Psychiatry 79, 516-525. doi: 10.1016/j.biopsych.2015.07.028

Lu, L., Uejima, J. L., Gray, S. M., Bossert, J. M., and Shaham, Y. (2007). Systemic and central amygdala injections of the mGluR $_{2 / 3}$ agonist LY379268 attenuate the expression of incubation of cocaine craving. Biol. Psychiatry 61, 591-598. doi: 10.1016/j.biopsych.2006.04.011

Lu, L., Xue, Y., Steketee, J. D., Rebec, G. V., and Sun, W. (2012). Regulation of cocaine-induced reinstatement by group II metabotropic glutamate receptors in the ventral tegmental area. Psychopharmacology (Berl) 220, 75-85. doi: 10. 1007/s00213-011-2455-5

Lupica, C. R., and Riegel, A. C. (2005). Endocannabinoid release from midbrain dopamine neurons: a potential substrate for cannabinoid receptor antagonist treatment of addiction. Neuropharmacology 48, 1105-1116. doi: 10.1016/j. neuropharm.2005.03.016

Mahler, S. V., Hensley-Simon, M., Tahsili-Fahadan, P., LaLumiere, R. T., Thomas, C., Fallon, R. V., et al. (2014). Modafinil attenuates reinstatement of cocaine seeking: role for cystine-glutamate exchange and metabotropic glutamate receptors. Addict. Biol. 19, 49-60. doi: 10.1111/j.1369-1600.2012. 00506.x

Manzoni, O., Michel, J. M., and Bockaert, J. (1997). Metabotropic glutamate receptors in the rat nucleus accumbens. Eur. J. Neurosci. 9, 1514-1523. doi: 10. 1111/j.1460-9568.1997.tb01506.x

Mao, L., Guo, M., Jin, D., Xue, B., and Wang, J. Q. (2013). Group III metabotropic glutamate receptors and drug addiction. Front. Med. 7, 445-451. doi: 10. 1007/s11684-013-0291-1

Mao, L., and Wang, J. Q. (1999). Protection against acute amphetamine-induced behavior by microinjection of a group II metabotropic glutamate receptor agonist into the dorsal striatum of rats. Neurosci. Lett. 270, 103-106. doi: 10. 1016/s0304-3940(99)00480-2

Martin-Fardon, R., and Weiss, F. (2012). (-)-2-oxa-4-aminobicylco[3.1.0]hexane4,6-dicarboxylic acid (LY379268) and 3-[(2-methyl-1,3-thiazol-4-yl)ethynyl] piperidine (MTEP) similarly attenuate stress-induced reinstatement of cocaine seeking. Addict. Biol. 17, 557-564. doi: 10.1111/j.1369-1600.2011. 00345.x

Martín-García, E., Bourgoin, L., Cathala, A., Kasanetz, F., Mondesir, M., Gutiérrez-Rodriguez, A., et al. (2016). Differential control of cocaine self-administration by GABAergic and glutamatergic CB1 cannabinoid receptors. Neuropsychopharmacology 41, 2192-2205. doi: 10.1038/npp. 2015.351

Mathews, T. A., John, C. E., Lapa, G. B., Budygin, E. A., and Jones, S. R. (2006). No role of the dopamine transporter in acute ethanol effects on striatal dopamine dynamics. Synapse 60, 288-294. doi: 10.1002/syn.20301

Mato, S., Chevaleyre, V., Robbe, D., Pazos, A., Castillo, P. E., and Manzoni, O. J. (2004). A single in-vivo exposure to $\triangle 9$ THC blocks endocannabinoidmediated synaptic plasticity. Nat. Neurosci. 7, 585-586. doi: 10.1038/ nn1251
Mato, S., Robbe, D., Puente, N., Grandes, P., and Manzoni, O. J. (2005). Presynaptic homeostatic plasticity rescues long-term depression after chronic $\Delta$ 9-tetrahydrocannabinol exposure. J. Neurosci. 25, 11619-11627. doi: 10. 1523/JNEUROSCI.2294-05.2005

Mattingly, B. A., Hart, T. C., Lim, K., and Perkins, C. (1994). Selective antagonism of dopamine D1 and D2 receptors does not block the development of behavioral sensitization to cocaine. Psychopharmacology (Berl) 114, 239-242. doi: 10.1007/bf02244843

McClure, E. A., Gipson, C. D., Malcolm, R. J., Kalivas, P. W., and Gray, K. M. (2014). Potential role of N-acetylcysteine in the management of substance use disorders. CNS Drugs 28, 95-106. doi: 10.1007/s40263-014$0142-\mathrm{x}$

McCutcheon, J. E., Loweth, J. A., Ford, K. A., Marinelli, M., Wolf, M. E., and Tseng, K. Y. (2011). Group I mGluR activation reverses cocaine-induced accumulation of calcium-permeable AMPA receptors in nucleus accumbens synapses via a protein kinase C-dependent mechanism. J. Neurosci. 31, 14536-14541. doi: 10.1523/JNEUROSCI.3625-11.2011

McReynolds, J. R., Doncheck, E. M., Vranjkovic, O., Ganzman, G. S., Baker, D. A., Hillard, C. J., et al. (2016). CB1 receptor antagonism blocks stress-potentiated reinstatement of cocaine seeking in rats. Psychopharmacology (Berl) 233, 99-109. doi: 10.1007/s00213-015-4092-x

Meinhardt, M. W., Hansson, A. C., Perreau-Lenz, S., Bauder-Wenz, C., Stählin, O., Heilig, M., et al. (2013). Rescue of infralimbic mGluR2 deficit restores control over drug-seeking behavior in alcohol dependence. J. Neurosci. 33, 2794-2806. doi: 10.1523/JNEUROSCI.4062-12.2013

Melis, M., Diana, M., Enrico, P., Marinelli, M., and Brodie, M. S. (2009). Ethanol and acetaldehyde action on central dopamine systems: mechanisms, modulation and relationship to stress. Alcohol 43, 531-539. doi: 10.1016/j. alcohol.2009.05.004

Mezler, M., Geneste, H., Gault, L., and Marek, G. J. (2010). LY-2140023, a prodrug of the group II metabotropic glutamate receptor agonist LY-404039 for the potential treatment of schizophrenia. Curr. Opin. Investig. Drugs 11, 833-845.

Miller, D. K., Rodvelt, K. R., Constales, C., and Putnam, W. C. (2007). Analogs of SR-141716A (Rimonabant) alter d-amphetamine-evoked [3H] dopamine overflow from preloaded striatal slices and amphetamine-induced hyperactivity. Life Sci. 81, 63-71. doi: 10.1016/j.lfs.2007.04.024

Miller, L. L., Ward, S. J., and Dykstra, L. A. (2008). Chronic unpredictable stress enhances cocaine-conditioned place preference in type 1 cannabinoid receptor knockout mice. Behav. Pharmacol. 19, 575-581. doi: 10.1097/FBP. 0b013e32830ded11

Morikawa, H., and Morrisett, R. A. (2010). Ethanol action on dopaminergic neurons in the ventral tegmental area: interaction with intrinsic ion channels and neurotransmitter inputs. Int. Rev. Neurobiol. 91, 235-288. doi: 10. 1016/s0074-7742(10)91008-8

Morishima, Y., Miyakawa, T., Furuyashiki, T., Tanaka, Y., Mizuma, H., and Nakanishi, S. (2005). Enhanced cocaine responsiveness and impaired motor coordination in metabotropic glutamate receptor subtype 2 knockout mice. Proc. Natl. Acad. Sci. U S A 102, 4170-4175. doi: 10.1073/pnas. 0500914102

Moro, F., Orrù, A., Marzo, C. M., Di Clemente, A., and Cervo, L. (2016). mGluR2/3 mediates short-term control of nicotine-seeking by acute systemic N-acetylcysteine. Addict. Biol. doi: 10.1111/adb.12443 [Epub ahead of print].

Moussawi, K., Pacchioni, A., Moran, M., Olive, M. F., Gass, J. T., Lavin, A., et al. (2009). N-Acetylcysteine reverses cocaine-induced metaplasticity. Nat. Neurosci. 12, 182-189. doi: 10.1038/nn.2250

Moussawi, K., Zhou, W., Shen, H., Reichel, C. M., See, R. E., Carr, D. B., et al. (2011). Reversing cocaine-induced synaptic potentiation provides enduring protection from relapse. Proc. Natl. Acad. Sci. U S A 108, 385-390. doi: 10. 1073/pnas. 1011265108

Navarro, M., Carrera, M. R., Fratta, W., Valverde, O., Cossu, G., Fattore, L., et al. (2001). Functional interaction between opioid and cannabinoid receptors in drug self-administration. J. Neurosci. 21, 5344-5350.

Nazarian, A., Russo, S. J., Festa, E. D., Kraish, M., and Quinones-Jenab, V. (2004). The role of D1 and D2 receptors in the cocaine conditioned place preference of male and female rats. Brain Res. Bull. 63, 295-299. doi: 10.1016/j.brainresbull. 2004.03.004 
Nazzaro, C., Greco, B., Cerovic, M., Baxter, P., Rubino, T., Trusel, M., et al. (2012). SK channel modulation rescues striatal plasticity and control over habit in cannabinoid tolerance. Nat. Neurosci. 15, 284-293. doi: 10.1038/nn.3022

Nestler, E. J., and Aghajanian, G. K. (1997). Molecular and cellular basis of addiction. Science 278, 58-63. doi: 10.1126/science.278.5335.58

Neugebauer, V., Zinebi, F., Russell, R., Gallagher, J. P., and Shinnick-Gallagher, P. (2000). Cocaine and kindling alter the sensitivity of group II and III metabotropic glutamate receptors in the central amygdala. J. Neurophysiol. 84, 759-770.

Nicola, S. M., Kombian, S. B., and Malenka, R. C. (1996). Psychostimulants depress excitatory synaptic transmission in the nucleus accumbens via presynaptic D1-like dopamine receptors. J. Neurosci. 16, 1591-1604.

Niswender, C. M., and Conn, P. J. (2010). Metabotropic glutamate receptors: physiology, pharmacology and disease. Annu. Rev. Pharmacol. Toxicol. 50, 295-322. doi: 10.1146/annurev.pharmtox.011008.145533

Orio, L., Edwards, S., George, O., Parsons, L. H., and Koob, G. F. (2009). A role for the endocannabinoid system in the increased motivation for cocaine in extended-access conditions. J. Neurosci. 29, 4846-4857. doi: 10 . 1523/JNEUROSCI.0563-09.2009

Ortinski, P. I., Vassoler, F. M., Carlson, G. C., and Pierce, R. C. (2012). Temporally dependent changes in cocaine-induced synaptic plasticity in the nucleus accumbens shell are reversed by D1-like dopamine receptor stimulation. Neuropsychopharmacology 37, 1671-1682. doi: 10.1038/npp.2012.12

Otani, S., Auclair, N., Desce, J. M., Roisin, M. P., and Crépel, F. (1999). Dopamine receptors and groups I and II mGluRs cooperate for long-term depression induction in rat prefrontal cortex through converging postsynaptic activation of MAP kinases. J. Neurosci. 19, 9788-9802.

Otani, S., Daniel, H., Takita, M., and Crépel, F. (2002). Long-term depression induced by postsynaptic group II metabotropic glutamate receptors linked to phospholipase $\mathrm{C}$ and intracellular calcium rises in rat prefrontal cortex. J. Neurosci. 22, 3434-3444.

Palmiter, R. D. (2008). Dopamine signaling in the dorsal striatum is essential for motivated behaviors: lessons from dopamine-deficient mice. Ann. N Y Acad. Sci. 1129, 35-46. doi: 10.1196/annals.1417.003

Pascoli, V., Terrier, J., Hiver, A., and Lüscher, C. (2015). Sufficiency of mesolimbic dopamine neuron stimulation for the progression to addiction. Neuron 88, 1054-1066. doi: 10.1016/j.neuron.2015.10.017

Patil, S. T., Zhang, L., Martenyi, F., Lowe, S. L., Jackson, K. A., Andreev, B. V., et al. (2007). Activation of mGlu2/3 receptors as a new approach to treat schizophrenia: a randomized Phase 2 clinical trial. Nat. Med. 13, 1102-1107. doi: $10.1038 / \mathrm{nm} 1632$

Pava, M. J., and Woodward, J. J. (2012). A review of the interactions between alcohol and the endocannabinoid system: implications for alcohol dependence and future directions for research. Alcohol 46, 185-204. doi: 10.1016/j.alcohol. 2012.01.002

Pehrson, A. L., and Moghaddam, B. (2010). Impact of metabotropic glutamate $2 / 3$ receptor stimulation on activated dopamine release and locomotion. Psychopharmacology (Berl) 211, 443-455. doi: 10.1007/s00213-010-1914-8

Perra, S., Pillolla, G., Melis, M., Muntoni, A. L., Gessa, G. L., and Pistis, M. (2005). Involvement of the endogenous cannabinoid system in the effects of alcohol in the mesolimbic reward circuit: electrophysiological evidence in vivo. Psychopharmacology (Berl) 183, 368-377. doi: 10.1007/s00213-005-0195-0

Peters, J., and Kalivas, P. W. (2006). The group II metabotropic glutamate receptor agonist, LY379268, inhibits both cocaine- and food-seeking behavior in rats. Psychopharmacology (Berl) 186, 143-149. doi: 10.1007/s00213-006-0372-9

Phillips, G. D., Robbins, T. W., and Everitt, B. J. (1994). Bilateral intra-accumbens self-administration of d-amphetamine: antagonism with intra-accumbens SCH-23390 and sulpiride. Psychopharmacology (Berl) 114, 477-485. doi: 10. 1007/bf02249339

Picone, R. P., and Kendall, D. A. (2015). Minireview: from the bench, toward the clinic: therapeutic opportunities for cannabinoid receptor modulation. Mol. Endocrinol. 29, 801-813. doi: 10.1210/me.2015-1062

Pidoplichko, V. I., Noguchi, J., Areola, O. O., Liang, Y., Peterson, J., Zhang, T., et al. (2004). Nicotinic cholinergic synaptic mechanisms in the ventral tegmental area contribute to nicotine addiction. Learn. Mem. 11, 60-69. doi: 10.1101/lm. 70004

Pierre, P. J., and Vezina, P. (1998). D1 dopamine receptor blockade prevents the facilitation of amphetamine self-administration induced by prior exposure to the drug. Psychopharmacology (Berl) 138, 159-166. doi: 10 $1007 / \mathrm{s} 002130050658$

Pina, M. M., and Cunningham, C. L. (2014). Effects of the novel cannabinoid CB1 receptor antagonist PF 514273 on the acquisition and expression of ethanol conditioned place preference. Alcohol 48, 427-431. doi: 10.1016/j. alcohol.2014.01.013

Pistillo, F., Fasoli, F., Moretti, M., McClure-Begley, T., Zoli, M., Marks, M. J., et al. (2016). Chronic nicotine and withdrawal affect glutamatergic but not nicotinic receptor expression in the mesocorticolimbic pathway in a regionspecific manner. Pharmacol. Res. 103, 167-176. doi: 10.1016/j.phrs.2015.11.016

Polissidis, A., Chouliara, O., Galanopoulos, A., Naxakis, G., Papahatjis, D., Papadopoulou-Daifoti, Z., et al. (2014). Cannabinoids negatively modulate striatal glutamate and dopamine release and behavioural output of acute Damphetamine. Behav. Brain Res. 270, 261-269. doi: 10.1016/j.bbr.2014.05.029

Price, M. R., Baillie, G. L., Thomas, A., Stevenson, L. A., Easson, M., Goodwin, R., et al. (2005). Allosteric modulation of the cannabinoid $\mathrm{CB}_{1}$ receptor. Mol. Pharmacol. 68, 1484-1495. doi: 10.1124/mol.105.016162

Rebec, G. V., White, I. M., and Puotz, J. K. (1997). Responses of neurons in dorsal striatum during amphetamine-induced focused stereotypy. Psychopharmacology (Berl) 130, 343-351. doi: 10.1007/s002130050249

Rezayof, A., Sardari, M., Zarrindast, M. R., and Nayer-Nouri, T. (2011). Functional interaction between morphine and central amygdala cannabinoid $\mathrm{CB} 1$ receptors in the acquisition and expression of conditioned place preference. Behav. Brain Res. 220, 1-8. doi: 10.1016/j.bbr.2011.01.023

Robbe, D., Alonso, G., Chaumont, S., Bockaert, J., and Manzoni, O. J. (2002a). Role of p/q-Ca2+ channels in metabotropic glutamate receptor 2/3-dependent presynaptic long-term depression at nucleus accumbens synapses. J. Neurosci. 22, 4346-4356.

Robbe, D., Bockaert, J., and Manzoni, O. J. (2002b). Metabotropic glutamate receptor 2/3-dependent long-term depression in the nucleus accumbens is blocked in morphine withdrawn mice. Eur. J. Neurosci. 16, 2231-2235. doi: 10. 1046/j.1460-9568.2002.2273.x

Roberto, M., Cruz, M., Bajo, M., Siggins, G. R., Parsons, L. H., and Schweitzer, P. (2010). The endocannabinoid system tonically regulates inhibitory transmission and depresses the effect of ethanol in central amygdala. Neuropsychopharmacology 35, 1962-1972. doi: 10.1038/npp.2010.70

Rodríguez De Fonseca, F., Gorriti, M. A., Fernández-Ruiz, J. J., Palomo, T., and Ramos, J. A. (1994). Downregulation of rat brain cannabinoid binding sites after chronic $\Delta 9$-tetrahydrocannabinol treatment. Pharmacol. Biochem. Behav. 47, 33-40. doi: 10.1016/0091-3057(94)90108-2

Romero, J., Garcia-Palomero, E., Castro, J. G., Garcia-Gil, L., Ramos, J. A., and Fernandez-Ruiz, J. J. (1997). Effects of chronic exposure to $\Delta^{9}$ tetrahydrocannabinol on cannabinoid receptor binding and mRNA levels in several rat brain regions. Mol. Brain Res. 46, 100-108. doi: 10.1016/s0169$328 \mathrm{x}(96) 00277-\mathrm{x}$

Rubino, T., Patrini, G., Massi, P., Fuzio, D., Viganò, D., Giagnoni, G., et al. (1998). Cannabinoid-precipitated withdrawal: a time-course study of the behavioral aspect and its correlation with cannabinoid receptors and $\mathrm{G}$ protein expression. J. Pharmacol. Exp. Ther. 285, 813-819.

Sala, M., and Braida, D. (2005). Endocannabinoids and 3,4methylenedioxymethamphetamine (MDMA) interaction. Pharmacol. Biochem. Behav. 81, 407-416. doi: 10.1016/j.pbb.2005.02.016

Salih, H., Anghelescu, I., Kezic, I., Sinha, V., Hoeben, E., Van Nueten, L., et al. (2015). Pharmacokinetic and pharmacodynamic characterisation of JNJ40411813 , a positive allosteric modulator of mGluR2, in two randomised, double-blind phase-I studies. J. Psychopharmacol. 29, 414-425. doi: 10. 1177/0269881115573403

Scatton, B., Simon, H., Le Moal, M., and Bischoff, S. (1980). Origin of dopaminergic innervation of the rat hippocampal formation. Neurosci. Lett. 18, 125-131. doi: 10.1016/0304-3940(80)90314-6

Schenk, S., Gittings, D., and Colussi-Mas, J. (2011). Dopaminergic mechanisms of reinstatement of MDMA-seeking behaviour in rats. Br. J. Pharmacol. 162, 1770-1780. doi: 10.1111/j.1476-5381.2010.01193.x

Schindler, C. W., Redhi, G. H., Vemuri, K., Makriyannis, A., Le Foll, B., Bergman, J., et al. (2016). Blockade of nicotine and cannabinoid reinforcement and relapse by a cannabinoid CB1-receptor neutral antagonist AM4113 and inverse agonist rimonabant in squirrel monkeys. Neuropsychopharmacology 41 , 2283-2293. doi: 10.1038/npp.2016.27 
Schultz, W. (2007). Behavioral dopamine signals. Trends Neurosci. 30, 203-210. doi: 10.1016/j.tins.2007.03.007

Schwendt, M., Reichel, C. M., and See, R. E. (2012). Extinction-dependent alterations in corticostriatal mGluR2/3 and mGluR7 receptors following chronic methamphetamine self-administration in rats. PLoS One 7:e34299. doi: 10.1371/journal.pone.0034299

Scofield, M. D., Heinsbroek, J. A., Gipson, C. D., Kupchik, Y. M., Spencer, S., Smith, A. C., et al. (2016). The nucleus accumbens: mechanisms of addiction across drug classes reflect the importance of glutamate homeostasis. Pharmacol. Rev. 68, 816-871. doi: 10.1124/pr.116.012484

Seino, S., and Shibasaki, T. (2005). PKA-dependent and PKA-independent pathways for cAMP-regulated exocytosis. Physiol. Rev. 85, 1303-1342. doi: 10. 1152/physrev.00001.2005

Self, D. W., Barnhart, W. J., Lehman, D. A., and Nestler, E. J. (1996). Opposite modulation of cocaine-seeking behavior by D1- and D2-like dopamine receptor agonists. Science 271, 1586-1589. doi: 10.1126/science.271.5255. 1586

Shaham, Y., and Stewart, J. (1996). Effects of opioid and dopamine receptor antagonists on relapse induced by stress and re-exposure to heroin in rats. Psychopharmacology (Berl) 125, 385-391. doi: 10.1007/bf02246022

Shippenberg, T. S., and Heidbreder, C. (1995). Sensitization to the conditioned rewarding effects of cocaine: pharmacological and temporal characteristics. J. Pharmacol. Exp. Ther. 273, 808-815.

Shoaib, M. (2008). The cannabinoid antagonist AM251 attenuates nicotine self-administration and nicotine-seeking behaviour in rats. Neuropharmacology 54, 438-444. doi: 10.1016/j.neuropharm.2007.10.011

Sidhpura, N., Weiss, F., and Martin-Fardon, R. (2010). Effects of the mGlu2/3 agonist LY379268 and the mGlu5 antagonist MTEP on ethanol seeking and reinforcement are differentially altered in rats with a history of ethanol dependence. Biol. Psychiatry 67, 804-811. doi: 10.1016/j.biopsych.2010. 01.005

Sim, H.-R., Choi, T.-Y., Lee, H. J., Kang, E. Y., Yoon, S., Han, P.-L., et al. (2013). Role of dopamine D2 receptors in plasticity of stress-induced addictive behaviours. Nat. Commun. 4:1579. doi: 10.1038/ncomms2598

Simonnet, A., Cador, M., and Caille, S. (2013). Nicotine reinforcement is reduced by cannabinoid CB1 receptor blockade in the ventral tegmental area. Addict. Biol. 18, 930-936. doi: 10.1111/j.1369-1600.2012.00476.x

Singleton, E. G., Trotman, A. J., Zavahir, M., Taylor, R. C., and Heishman, S. J. (2002). Determination of the reliability and validity of the Marijuana craving questionnaire using imagery scripts. Exp. Clin. Psychopharmacol. 10, 47-53. doi: 10.1037/1064-1297.10.1.47

Solinas, M., Panlilio, L. V., Antoniou, K., Pappas, L. A., and Goldberg, S. R. (2003). The cannabinoid CB1 antagonist N-piperidinyl-5-(4-chlorophenyl)1-(2,4-dichlorophenyl) -4-methylpyrazole-3-carboxamide (SR-141716A) differentially alters the reinforcing effects of heroin under continuous reinforcement, fixed ratio and progressive ratio schedules of drug self-administration in rats. J. Pharmacol. Exp. Ther. 306, 93-102. doi: 10. 1124/jpet.102.047928

Soyka, M., and Mutschler, J. (2016). Treatment-refractory substance use disorder: focus on alcohol, opioids and cocaine. Prog. Neuropsychopharmacol. Biol. Psychiatry 70, 148-161. doi: 10.1016/j.pnpbp.2015.11.003

Spealman, R. D., Barrett-Larimore, R. L., Rowlett, J. K., Platt, D. M., and Khroyan, T. V. (1999). Pharmacological and environmental determinants of relapse to cocaine-seeking behavior. Pharmacol. Biochem. Behav. 64, 327-336. doi: 10.1016/s0091-3057(99)00049-0

Spealman, R. D., Bergman, J., Madras, B. K., Kamien, J. B., and Melia, K. F. (1992). Role of D1 and D2 dopamine receptors in the behavioral effects of cocaine. Neurochem. Int. 20, (Suppl.) 147S-152S. doi: 10.1016/0197-0186(92) $90228-\mathrm{j}$

Spyraki, C., Fibiger, H. C., and Phillips, A. G. (1982). Cocaine-induced place preference conditioning: lack of effects of neuroleptics and 6-hydroxydopamine lesions. Brain Res. 253, 195-203. doi: 10.1016/00068993(82) $90686-2$

Stamatakis, A. M., Sparta, D. R., Jennings, J. H., McElligott, Z. A., Decot, H., and Stuber, G. D. (2014). Amygdala and bed nucleus of the stria terminalis circuitry: implications for addiction-related behaviors. Neuropharmacology 76, 320-328. doi: 10.1016/j.neuropharm.2013.05.046
Steketee, J. D. (1998). Injection of SCH 23390 into the ventral tegmental area blocks the development of neurochemical but not behavioral sensitization to cocaine. Behav. Pharmacol. 9, 69-76.

Stobbs, S. H., Ohran, A. J., Lassen, M. B., Allison, D. W., Brown, J. E., and Steffensen, S. C. (2004). Ethanol suppression of ventral tegmental area GABA neuron electrical transmission involves $\mathrm{N}$-methyl-D-aspartate receptors. J. Pharmacol. Exp. Ther. 311, 282-289. doi: 10.1124/jpet.104. 071860

Szabo, B., Siemes, S., and Wallmichrath, I. (2002). Inhibition of gabaergic neurotransmission in the ventral tegmental area by cannabinoids. Eur. J. Neurosci. 15, 2057-2061. doi: 10.1046/j.1460-9568.2002.02041.x

Talani, G., and Lovinger, D. M. (2015). Interactions between ethanol and the endocannabinoid system at GABAergic synapses on basolateral amygdala principal neurons. Alcohol 49, 781-794. doi: 10.1016/j.alcohol.2015. 08.006

Tan, K. R., Brown, M., Labouèbe, G., Yvon, C., Creton, C., Fritschy, J. M., et al. (2010). Neural bases for addictive properties of benzodiazepines. Nature 463, 769-774. doi: 10.1038/nature08758

Tanda, G., Munzar, P., and Goldberg, S. R. (2000). Self-administration behavior is maintained by the psychoactive ingredient of marijuana in squirrel monkeys. Nat. Neurosci. 3, 1073-1074. doi: 10.1038/80577

Tateno, T., and Robinson, H. P. (2011). The mechanism of ethanol action on midbrain dopaminergic neuron firing: a dynamic-clamp study of the role of $\mathrm{I}_{\mathrm{h}}$ and GABAergic synaptic integration. J. Neurophysiol. 106, 1901-1922. doi: 10. 1016/j.neures.2011.07.1371

Thanos, P. K., Dimitrakakis, E. S., Rice, O., Gifford, A., and Volkow, N. D. (2005). Ethanol self-administration and ethanol conditioned place preference are reduced in mice lacking cannabinoid CB1 receptors. Behav. Brain Res. 164 , 206-213. doi: 10.1016/j.bbr.2005.06.021

Theile, J. W., Morikawa, H., Gonzales, R. A., and Morrisett, R. A. (2011). GABAergic transmission modulates ethanol excitation of ventral tegmental area dopamine neurons. Neuroscience 172, 94-103. doi: 10.1016/j.neuroscience. 2010.10 .046

Touriño, C., Ledent, C., Maldonado, R., and Valverde, O. (2008). CB1 cannabinoid receptor modulates 3,4-methylenedioxymethamphetamine acute responses and reinforcement. Biol. Psychiatry 63, 1030-1038. doi: 10.1016/j.biopsych. 2007.09.003

Ujike, H., Akiyama, K., and Otsuki, S. (1990). D-2 but not D-1 dopamine agonists produce augmented behavioral response in rats after subchronic treatment with methamphetamine or cocaine. Psychopharmacology (Berl) 102, 459-464. doi: $10.1007 / \mathrm{bf} 02247125$

Ushijima, I., Carino, M. A., and Horita, A. (1995). Involvement of D1 and D2 dopamine systems in the behavioral effects of cocaine in rats. Pharmacol. Biochem. Behav. 52, 737-741. doi: 10.1016/0091-3057(95) 00167-u

Valjent, E., and Maldonado, R. (2000). A behavioural model to reveal place preference to $\Delta$ 9-tetrahydrocannabinol in mice. Psychopharmacology (Berl) 147, 436-438. doi: 10.1007/s002130050013

Vallée, M., Vitiello, S., Bellocchio, L., Hébert-Chatelain, E., Monlezun, S., MartinGarcia, E., et al. (2014). Pregnenolone can protect the brain from cannabis intoxication. Science 343, 94-98. doi: 10.1126/science.1243985

Vanderschuren, L. J., and Kalivas, P. W. (2000). Alterations in dopaminergic and glutamatergic transmission in the induction and expression of behavioral sensitization: a critical review of preclinical studies. Psychopharmacology (Berl) 151, 99-120. doi: 10.1007/s002130000493

Vanover, K. E., Kleven, M. S., and Woolverton, W. L. (1991). Blockade of the discriminative stimulus effects of cocaine in rhesus monkeys with the D(1) dopamine antagonists SCH-39166 and A-66359. Behav. Pharmacol. 2, 151-159. doi: 10.1097/00008877-199104000-00007

Varodayan, F. P., Bajo, M., Soni, N., Luu, G., Madamba, S. G., Schweitzer, P., et al. (2016a). Chronic alcohol exposure disrupts CB1 regulation of GABAergic transmission in the rat basolateral amygdala. Addict. Biol. doi: 10.1111/adb. 12369 [Epub ahead of print].

Varodayan, F. P., Soni, N., Bajo, M., Luu, G., Madamba, S. G., Schweitzer, P., et al. (2016b). Chronic ethanol exposure decreases CB1 receptor function at GABAergic synapses in the rat central amygdala. Addict. Biol. 21, 788-801. doi: $10.1111 / \mathrm{adb} .12256$ 
Vaughn, L. K., Mantsch, J. R., Vranjkovic, O., Stroh, G., Lacourt, M., Kreutter, M., et al. (2012). Cannabinoid receptor involvement in stress-induced cocaine reinstatement: potential interaction with noradrenergic pathways. Neuroscience 204, 117-124. doi: 10.1016/j.neuroscience.2011.08.021

Volkow, N. D., Fowler, J. S., Wang, G. J., Baler, R., and Telang, F. (2009). Imaging dopamine's role in drug abuse and addiction. Neuropharmacology 56, 3-8. doi: 10.1016/j.neuropharm.2008.05.022

Volkow, N. D., Koob, G., and Baler, R. (2015). Biomarkers in substance use disorders. ACS Chem. Neurosci. 6, 522-525. doi: 10.1021/acschemneuro. 5 b00067

Volkow, N. D., and Morales, M. (2015). The brain on drugs: from reward to addiction. Cell 162, 712-725. doi: 10.1016/j.cell.2015.07.046

Volkow, N. D., Wang, G.-J., Telang, F., Fowler, J. S., Alexoff, D., Logan, J., et al. (2014). Decreased dopamine brain reactivity in marijuana abusers is associated with negative emotionality and addiction severity. Proc. Natl. Acad. Sci. U S A 111, E3149-E3156. doi: 10.1073/pnas.1411228111

Walker, A. G., Wenthur, C. J., Xiang, Z., Rook, J. M., Emmitte, K. A., Niswender, C. M., et al. (2015). Metabotropic glutamate receptor 3 activation is required for long-term depression in medial prefrontal cortex and fear extinction. Proc. Natl. Acad. Sci. U S A 112, 1196-1201. doi: 10.1073/pnas. 1416196112

Wang, H., and Lupica, C. R. (2014). Release of endogenous cannabinoids from ventral tegmental area dopamine neurons and the modulation of synaptic processes. Prog. Neuropsychopharmacol. Biol. Psychiatry 52, 24-27. doi: 10. 1016/j.pnpbp.2014.01.019

Wang, H., Treadway, T., Covey, D. P., Cheer, J. F., and Lupica, C. R. (2015). Cocaine-induced endocannabinoid mobilization in the ventral tegmental area. Cell Rep. 12, 1997-2008. doi: 10.1016/j.celrep.2015.08.041

Ward, S. J., Rosenberg, M., Dykstra, L. A., and Walker, E. A. (2009). The CB1 antagonist rimonabant (SR141716) blocks cue-induced reinstatement of cocaine seeking and other context and extinction phenomena predictive of relapse. Drug Alcohol Depend. 105, 248-255. doi: 10.1016/j.drugalcdep.2009. 07.002

Weiland, B. J., Thayer, R. E., Depue, B. E., Sabbineni, A., Bryan, A. D., and Hutchison, K. E. (2015). Daily marijuana use is not associated with brain morphometric measures in adolescents or adults. J. Neurosci. 35, 1505-1512. doi: 10.1523/JNEUROSCI.2946-14.2015

Welter, M., Vallone, D., Samad, T. A., Meziane, H., Usiello, A., and Borrelli, E. (2007). Absence of dopamine D2 receptors unmasks an inhibitory control over the brain circuitries activated by cocaine. Proc. Natl. Acad. Sci. U S A 104, 6840-6845. doi: 10.1073/pnas.0610790104

White, F. J., Joshi, A., Koeltzow, T. E., and Hu, X. T. (1998). Dopamine receptor antagonists fail to prevent induction of cocaine sensitization. Neuropsychopharmacology 18, 26-40. doi: 10.1016/S0893-133X(97)00093-6

Wickens, J. R., Horvitz, J. C., Costa, R. M., and Killcross, S. (2007). Dopaminergic mechanisms in actions and habits. J. Neurosci. 27, 8181-8183. doi: 10 . 1523/JNEUROSCI.1671-07.2007

Wiley, J. L., and Martin, B. R. (2003). Cannabinoid pharmacological properties common to other centrally acting drugs. Eur. J. Pharmacol. 471, 185-193. doi: 10.1016/s0014-2999(03)01856-9

Witkin, J. M., Schindler, C. W., Tella, S. R., and Goldberg, S. R. (1991). Interaction of haloperidol and SCH 23390 with cocaine and dopamine receptor subtype-selective agonists on schedule-controlled behavior of squirrel monkeys. Psychopharmacology (Berl) 104, 425-431. doi: 10.1007/bf02 245644

Wood, C. M., Nicolas, C. S., Choi, S. L., Roman, E., Nylander, I., FernandezTeruel, A., et al. (2016). Prevalence and influence of cys 407 * Grm2 mutation in Hannover-derived Wistar rats: mGlu2 receptor loss links to alcohol intake, risk taking and emotional behaviour. Neuropharmacology doi: 10.1016/j. neuropharm.2016.03.020 [Epub ahead of print].

Woolverton, W. L. (1986). Effects of a D1 and a D2 dopamine antagonist on the self-administration of cocaine and piribedil by rhesus monkeys. Pharmacol. Biochem. Behav. 24, 531-535. doi: 10.1016/0091-3057(86)90553-8

Xi, Z.-X., Ramamoorthy, S., Baker, D. A., Shen, H., Samuvel, D. J., and Kalivas, P. W. (2002). Modulation of group II metabotropic glutamate receptor signaling by chronic cocaine. J. Pharmacol. Exp. Ther. 303, 608-615. doi: 10. 1124/jpet.102.039735

Xi, Z. X., Spiller, K., Pak, A. C., Gilbert, J., Dillon, C., Li, X., et al. (2008). Cannabinoid CB1 receptor antagonists attenuate cocaine's rewarding effects: experiments with self-administration and brain-stimulation reward in rats. Neuropsychopharmacology 33, 1735-1745. doi: 10.1038/sj.npp.1301552

Xia, J. X., Li, J., Zhou, R., Zhang, X. H., Ge, Y. B., and Ru Yuan, X. (2006). Alterations of rat corticostriatal synaptic plasticity after chronic ethanol exposure and withdrawal. Alcohol. Clin. Exp. Res. 30, 819-824. doi: 10.1111/j. 1530-0277.2006.00095.x

Xie, X., and Steketee, J. D. (2008). Repeated exposure to cocaine alters the modulation of mesocorticolimbic glutamate transmission by medial prefrontal cortex Group II metabotropic glutamate receptors. J. Neurochem. 107, 186-196. doi: 10.1111/j.1471-4159.2008.05593.x

Xie, X., and Steketee, J. D. (2009). Effects of repeated exposure to cocaine on group II metabotropic glutamate receptor function in the rat medial prefrontal cortex: behavioral and neurochemical studies. Psychopharmacology (Berl) 203, 501-510. doi: 10.1007/s00213-008-1392-4

Yi, S. J., and Johnson, K. M. (1990). Chronic cocaine treatment impairs the regulation of synaptosomal $3 \mathrm{H}-\mathrm{DA}$ release by D2 autoreceptors. Pharmacol. Biochem. Behav. 36, 457-461. doi: 10.1016/0091-3057(90)90241-9

Yin, H. H. (2016). The basal ganglia in action. Neuroscientist doi: 10 . $1177 / 1073858416654115$ [Epub ahead of print].

Yu, L.-L., Wang, X.-Y., Zhao, M., Liu, Y., Li, Y.-Q., Li, F.-Q., et al. (2009). Effects of cannabinoid CB1 receptor antagonist rimonabant in consolidation and reconsolidation of methamphetamine reward memory in mice. Psychopharmacology (Berl) 204, 203-211. doi: 10.1007/s00213-008$1450-\mathrm{y}$

Zangen, A., Solinas, M., Ikemoto, S., Goldberg, S. R., and Wise, R. A. (2006). Two brain sites for cannabinoid reward. J. Neurosci. 26, 4901-4907. doi: 10. 1523/JNEUROSCI.3554-05.2006

Zhao, Y., Dayas, C. V., Aujla, H., Baptista, M. A., Martin-Fardon, R., and Weiss, F. (2006). Activation of group II metabotropic glutamate receptors attenuates both stress and cue-induced ethanol-seeking and modulates c-fos expression in the hippocampus and amygdala. J. Neurosci. 26, 9967-9974. doi: 10.1523/JNEUROSCI.2384-06.2006

Zhou, Z., Karlsson, C., Liang, T., Xiong, W., Kimura, M., Tapocik, J. D., et al. (2013). Loss of metabotropic glutamate receptor 2 escalates alcohol consumption. Proc. Natl. Acad. Sci. U S A 110, 16963-16968. doi: 10.1073/pnas. 1309839110

Conflict of Interest Statement: The authors declare that the research was conducted in the absence of any commercial or financial relationships that could be construed as a potential conflict of interest.

Copyright (C) 2016 Johnson and Lovinger. This is an open-access article distributed under the terms of the Creative Commons Attribution License (CC BY). The use, distribution and reproduction in other forums is permitted, provided the original author(s) or licensor are credited and that the original publication in this journal is cited, in accordance with accepted academic practice. No use, distribution or reproduction is permitted which does not comply with these terms. 